\title{
Phytostabilization of massive mine wastes with native phytogenetic resources: potential for sustainable use and conservation of the native flora in north-central Chile
}

\author{
Cristina Orchard ${ }^{1}$, Pedro León-Lobos ${ }^{2}$, and Rosanna Ginocchio ${ }^{1,3}$ \\ ${ }^{1}$ Facultad de Agronomía e Ingeniería Forestal, Pontificia Universidad Católica de Chile, Av. Vicuña \\ Mackenna 4860, Macul, Santiago, Chile. \\ ${ }^{2}$ Instituto de Investigaciones Agropecuarias, INIA-Intihuasi, Colina San Joaquín s/n, La Serena, Chile. \\ ${ }^{3}$ Centro de Investigación Minera y Metalúrgica, CIMM, Av. Parque Antonio Rabat 6500, Vitacura, \\ Santiago, Chile.
}

\begin{abstract}
C. Orchard, P. León-Lobos, and R. Ginocchio. 2009. Phytostabilization of massive mine wastes with native phytogenetic resources: potential for sustainable use and conservation of the native flora in north-central Chile. Cien. Inv. Agr. 36(3):329-352. The mining industry has left an important legacy of inadequately abandoned tailing storage facilities (TSFs) in the north-central area of Chile, and they may pose environmental risks. The Chilean government has recently established new regulations governing the closure of TSFs, and these regulations favor the use of environmentally sustainable technologies. Among these technologies is phytostabilization, which can use native plant species that may also have economic and/or subsistence value. Phytostabilization programs based on sustainably maintained native species could also contribute to the conservation of both local flora and regional ecosystems in north-central Chile. The main objective of this study was to use the Coquimbo Region as a case study area to look for added economic value from native plant species that have spontaneously colonized abandoned TSFs and to look for other species that, given their ecological characteristics, may be established on post-operational TSFs by phytostabilization. A review of technical, scientific and ethnobotanic literature on traditional uses and recently discovered uses of selected plant species was performed. The results showed that 68 spontaneously colonizing phytostabilization species have at least one known use, while 420 species with potential for use in phytostabilization ( $28 \%$ of the regional native flora) have various uses. Ornamentation, cattle forage, mellipherous, medicine, crafts and phytochemicals are the main uses identified for the local native flora. Most of the identified species are endemic to Chile (69\%). These species are therefore a very valuable phytogenetic resource that can be used in the rehabilitation of massive mine wastes. This unique resource could be lost if these species are not identified and studied in the near future.
\end{abstract}

Key words: Mine tailings, mining, natural resources, rehabilitation, sustainable management, valuation of natural resources.

\section{Introduction}

Mining is an important industrial activity for the Chilean economy, but it poses risks for the

Received 05 September 2008. Accepted 27

November 2008.

Corresponding author: rginocc@cimm.cl environment, the silvoagropecuarian sector and human health, resulting mainly from the production of massive quantities of solid waste. Mining operations may affect water, soil, air, topography, flora and fauna, and they range from small modifications to large ecosystemic degradations (Bell, 1999; Sánchez, 2002; Ginocchio, 2004; Martin and Ruby, 2004). The current growing world demand for metals and the consequent 
loss of biodiversity are threatening the continuity of the ecosystems that we all depend on, especially the poorest rural communities (ICMM, 2006).

The mining industry has had a considerable impact during the 19th century in Norte Chico, Chile. The copper industry consumed huge amounts of firewood in furnaces and thereby set in motion a sustained process of vegetative decay that changed the local landscape irreversibly (Folchi, 2001; Brown et al. 2003). Moreover, from 1938 until 1975 the tailings from the Potrerillos mine (III Region of Atacama) were released into Río Salado and the Chañaral Bay. This resulted in the accumulation of tailings more than 10 meters thick covering a surface of around $4 \mathrm{~km}^{2}$ and the displacement of the coastline by approximately $1 \mathrm{~km}$. Since then, the zone has been exposed, and eolic transportation of the contaminating material has occurred, resulting in one of the most serious cases of contamination in the Pacific Ocean (Dold, 2007).

Among the residuals generated by the mining activity, the tailings represent $50 \%$ of the solid waste of the extractive process, and they are responsible for most of the environmental problems generated by mining activities in Chile (Espinoza et al., 1991; López et al., 2003). From 1970 , tailings have been compulsorily accrued in artificial dams where suspended solids precipitate, as expressed in the Supreme Decree $\mathrm{N}^{\mathrm{o}}$ 86 of the Ministry of Mining of Chile (Rubio, 2007). However, the lack of environmental legislation concerning the post-operations stage of tailing deposits resulted in the inappropriate neglect of a large number of deposits in the semiarid north-central zone of the country (Ginocchio, 2004). Once the tailing dams reach the end of their service life, they begin to dehydrate due to the semiarid Mediterranean climate conditions predominant in central Chile, and this exposes the fine particles to dispersion agents such as wind and rain. Additionally, they may react with water and oxygen to generate acid drainage and metal lixiviation, thereby contaminating nearby water courses and soils (Goodman, 1974; Bell, 1999; Santibáñez, 2006). Nevertheless, the current regulations are intended to rehabilitate the area (Ministry of Mining, 2004, 2007). In addition to highlighting the use of environmentally sustainable technologies, these regulations prevent the dispersion of metals and toxic metalloids into the environment by demanding that mining operations be closed in such a way that tailing deposits are stabilized before they are abandoned.

The rehabilitation of areas degraded by mining has been implemented in various developed countries as an important instrument of public politics in the environmental area. For example, in the United States, France, Italy, Russia, and Canada, the rehabilitation of areas degraded by mining activities is compulsory, and methodologies where environmental stability and sustainability is effectively guaranteed are favored. In the case of South America, mandatory rehabilitation has been increasingly considered in the legal regulations of countries such as Chile, Brazil, Argentina, Peru, Colombia and Uruguay. Even though such legislation is not a public priority in most countries, the inclusion of degraded area rehabilitation among the instruments of environmental management applicable to the mining industry has been growing due to international standardization of environmental regulations in the business sector (International Organization for Standardization, ISO) (Yazbek, 2002).

Among the emerging technologies for the rehabilitation of degraded areas, phytostabilization has proven to be an efficient, environmentally appropriate and relatively low cost approach (Berti and Cunningham, 2000; Petrisor et al., 2004). In relation to mining wastes, phytostabilization consists of setting out metallophyte plants, applying appropriate substrate amendments. Plants that can tolerate the high metal concentrations of the substrate are part of a program of ecological rehabilitation that physically, chemically and biologically stabilizes the substrate and the tailings' toxicity. This technology reduces metal dispersion in the environment, reduces the metal bioavailability for living beings, and returns the substrate to an acceptable ecological condition for diverse future uses (Berti and Cunningham, 2000; Dietz and Schnoor, 2001; Martin and Ruby, 2004; Ginocchio and León-Lobos, 2007). Unlike other existing methods, phytostabilization may be applied over larger areas and presents 
a favorable cost-benefit ratio. This ratio may be further improved by using metallophyte plants with other uses (added value), which could also benefit the economic development of local communities (Ginocchio, 2004; Petrisor et al., 2004; SONAMI, 2006).

Using native/endemic plants that are adapted to the climatic, geographical and metallogenic conditions of the zone could add value to phytostabilization programs and place this technology ahead of other existing technologies. Many of the native and endemic vegetal species of north central Chile have been traditionally used to meet the needs of rural communities. Local plant species serve as foods, medicines and construction materials, among other things, and they constitute a biological heritage that is strategically situated for rural economical development (Montenegro, 2000; León-Lobos et al., 2007). However, most of these resources are almost unknown and they have not been used at productive scales. Assessment of the Chilean flora, whether by its intrinsic biological value or by the benefit that it may provide, will contribute to its conservation. Just as the sustainable management of wild fauna has promoted the survival of these species, the sustainable management of wild flora may promote the conservation of species of interest and the biological communities they belong to (Primack et al., 2001). Sustainable management that conserves biodiversity can also address economic and subsistence needs. The sustainable use of biodiversity and conservation based on the community (acknowledging the importance of involving the local communities in the conservation schemes) are two contemporaneous conservation tools that are intended to include the socio-economical development of local communities and their direct participation in the politics of wildlife conservation (Campbell, 2000).

In addition to alleviating the impacts generated by mining wastes, the use of vegetal native/endemic species in phytostabilization programs would promote conservation of the flora and ecosystems of north-central Chile (Whiting et al., 2004) through the incorporation of native and endemic species, especially those that are vulnerable or endangered. Therefore, ecological rehabilitation is expected to make an impor- tant contribution to biodiversity conservation (Dobson et al., 1997; Young, 2000). Good practices, collaboration among the different sectors involved and innovative thinking should contribute to biodiversity conservation, ensure responsible mining production and minimize the conflicts of interest (IUCN and ICMM, 2004).

In this context, the objective of this study was to identify (through a bibliographical review) native vegetal species of the Region of Coquimbo that could be used in the phytostabilization of post-operative mining tailing deposits, with the goal of promoting this technology over other existing technologies. Although the native flora of the Region of Coquimbo represents a study case, most of the species identified have a distribution range covering other regions of the country where the stabilization of mining tailing deposits is also an urgent need; therefore, the application of this study could be extended to north-central Chile. In addition, the importance of including native/endemic species that may provide added value to the phytostabilization programs for the conservation of the native flora is still under discussion.

\section{Rehabilitation of tailing storage facilities in the Region of Coquimbo through phytostabilization}

Metallic mining has consistently contributed to the economic growth of the Region of Coquimbo, Chile, which, since the beginning, has maintained constant production levels. Currently it accounts for $23 \%$ of the gross domestic product (GDP) and $80 \%$ of regional exports, with copper and iron the most relevant metals (INE, 2008). Villages completely involved in mining, like Andacollo, have historically maintained whole populations deeply linked to the extraction and processing of minerals (Brown et al., 2003). However, the large volume of past and current wastes generated by this industry has resulted in a legacy of around 360 tailing storage facilities distributed throughout the region. Fully $98 \%$ of these are located in the coastal strip, in the midelevation mountain area and transverse valleys (SERNAGEOMIN, 1990), which coincides with areas of human occupation. Due to the proxim- 
ity of important agricultural, cattle, residential and ecological sectors to tailing deposits in the Region of Coquimbo, and how disastrous contamination of the scarce water resources would be, it is essential that the tailing deposits present in the region be stabilized effectively in the short and in the long term to protect the substrate from water and eolic erosion that carries toxic material. It is also important to develop natural environmentally sustainable systems that allow the recolonization of native species and that can serve as shelter for the fauna (Vega, 1999).

The various techniques used in tailing stabilization are intended to mitigate either the environmental or visual impacts, and some techniques are more efficient than others. For example, some mining companies in Brazil have responded to the demands for environmental mitigation of waste deposits and exploited areas with reforestation programs based on a few fast-growing exotic species. Specifically, the use of eucalyptus (Eucalyptus spp) has been promoted, even though long-term studies have shown that these programs would provoke a successional block due to the negative allelopathic effects of these vegetal species that reduce biodiversity in comparison with natural regeneration or replanting with native species (Primack and Massardo, 2001). This situation is not unknown in Chile, where rehabilitation based on the transplantation of exotic trees such as Australian eucalyptus and acacias have been used as the main tool for stabilizing the massive mining residues in the closure stage. However, the traditional method of forestation has not proven to be a long-term sustainable mechanism that ensures the physical and chemical stabilization of the residues and the integral functionality of the ecosystem. The constant addition of chemical fertilizers is necessary to ensure tree growth. Additionally, the environmental impacts have even been magnified via the mobilization of metals and metalloids through the food chain (Ginocchio, 2004).

Among the technologies used by industrialized countries to treat substrate enriched with metals are: 1) the excavation and disposal of dangerous wastes in landfills; 2) the retaining alternatives (such as cementing and vitrification); 3) chemical extraction; and 4) electrokinetics (Glass, 2000; Martin and Ruby, 2004). However, these techniques are extremely expensive, environmentally invasive and they result in a substrate altered in its physical, chemical and biological properties. These techniques further restrict the usefulness of the substrate, and furthermore, they are generally disapproved of by the local community (Ginocchio and León-Lobos, 2007). The need to apply these treatments may be avoided if the original soil has been removed before the mining activities and is used to recover the degraded area, as is required for surface mining in many developed countries (Dobson et al., 1997).

Alternatively, phytostabilization is a technology that reduces the risk of contamination caused by deposits of massive mining wastes by including plants able to tolerate the high concentrations of metals and the appropriate substrate amendments. By this technology, the bioavailable metals are precipitated, absorbed and/or adsorbed by the materials added to the substrate, by plant roots and by microorganisms, where they accrue in innocuous forms (Berti and Cunningham, 2000; Dietz and Schnoor, 2001; Ginocchio and León-Lobos, 2007). The implementation of a radicular system and a vegetal cover on the substrate also allows its physical stabilization, and this hinders the eolic/water dispersion of the particulated material rich in metals towards nearby water courses and soils. In addition, it helps to control the oxygen diffusion and the water percolating through tailings, as it creates a demand by plants, reducing the risk of acid drainage and metal lixiviation (Miller, 1996; Berti and Cunningham, 2000; Martin and Ruby, 2004; Santibáñez, 2006). This technology helps to accelerate the processes of vegetal repopulation (succession) that normally occur in terms of hundreds or thousand of years. Therefore, it accelerates the rebuilding of a natural autosustainable functional system that is integrated to the rest of the environment (Piha et al., 1995).

In addition to being tolerant of high concentrations of metals, the plants chosen for phytostabilization should be deficient in their translocation towards aerial tissues. This excluder metallophyte plants avoids the introduction of contaminants into local food chains that could have toxic effects on other living beings (Berti and 
Cunningham, 2000; Ginocchio, 2004). Normal levels of metals in aerial vegetal tissues reduce the need to treat harvested structures as dangerous wastes, which reduces costs and simplifies program management (Miller, 1996; Prasad and Freitas, 2003). In addition, the plants should tolerate other adverse conditions presented by tailing deposits, such as scarce nutrients, salinity and the lack of substrate structure, among other things. The plants should be easily set and cared for, fast-growing, and able to develop a dense radicular system so as to generate vegetation cover as fast as possible (Berti and Cunningham, 2000).

Phytostabilization programs developed in Europe and the United States have preferred the use of native/endemic metallophyte plants adapted to the local conditions over exotic species. Exotic species are often invading species that alter the dynamics of wild biological communities and/or agriculture near the work site, and they are not always appropriate to the climatic and geographical conditions of the site, which may increase maintenance costs in the long term (Ginocchio, 2004; Conesa et al., 2007; Mahmud et al., 2008). Metallophyte species are typically endemic to their metallic native areas; therefore, considering that the mineralized substrates where these species develop are the material of interest, they are susceptible to high rates of population decline and even extinction (Whiting et al., 2004).

Although the vegetation that spontaneously colonizes mining zones has been studied in other arid and semiarid regions of the world (Conesa et al., 2007), knowledge of the metallophyte species of north-central Chile is virtually nonexistent. This lack of knowledge contrasts with the potential richness of metallophyte species in an area where the native and endemic Mediterranean flora have developed naturally and evolved for millions of years in the presence of numerous mineral deposits (Ginocchio and Baker, 2004). However, recent investigations in the Region of Coquimbo have identified vegetal species able to spontaneously colonize abandoned tailing deposits as well as species tolerant to high copper concentrations (Ginocchio et al., 2007). On the other hand, it is possible that other species present in the region are also ap- propriate for planting on mining tailings in the context of phytostabilization technology. Some species have seed dispersion mechanisms that could be hindering their colonization of abandoned tailing dams, which may be currently limited to species dispersed by wind. Birds or other animals scattering seeds probably have avoided these dams due to the lack of 'hangers' to land on or to the inhospitable conditions that these dams sustain. Additionally, even if the seeds reach the tailings, the environmental conditions could inhibit germination.

The Region of Coquimbo harbors the richest collection of vascular plants in the country (Squeo et al., 2001a). Among these local plants, many might be appropriate for inclusion in phytostabilization programs for abandoned post-operative tailing storage facilities of the region, including plants with the correct ecological features, the correct adaptability patterns (tolerance to high solar radiation, scarce water and limited nutritional resources) and plants phylogenetically related to metallophyte species from other arid regions of the world (i.e., belonging to the same family or genus). Therefore, the species spontaneously colonizing tailing deposits and the species potentially usable in phytostabilization programs represent valuable phytogenetic resources for the rehabilitation of massive mining wastes, and they could offer productive and support uses, thereby fostering the conservation of these species and the local ecosystems.

\section{Native flora of the Region of Coquimbo: Diversity, state of conservation and alternative uses}

Located in the transitional zone between the semiarid Mediterranean region and the desert areas to the north, the Region of Coquimbo gathers a wide range of biogeographical elements, including numerous genera that have experienced significant developmental radiations, as well as relict communities containing species more typical of the temperate southern forests. On the other hand, many species in the region are at their latitudinal limit of distribution; 628 species reach their northern distribution limit in the region while 288 species reach their southern limit (as a whole, $62 \%$ of the native regional 
species). This phenomenon may be explained by the transitional environmental conditions, which are characterized by a semiarid Mediterranean type climate. The wide range of biogeographical elements present is consistent with the high level of regional endemism and the presence of many species susceptible to habitat reduction (Squeo and Arroyo, 2001). Central Chile has been included within the 25 "World Biodiversity Hotspots for Conservation Priority" due to the concentration of endemic species and their exposure to high threat levels (Myers et al., 2000). Within this area of high biodiversity, the Region de Coquimbo represents the northern limit.

The native and naturalized flora inhabiting the Region of Coquimbo is composed of 1,727 species, 1,478 of which are native to Chile and 140 are endemic to the region (Marticorena et al., 2001). The hemicryptophyte species are predominant in the native regional flora, followed by the phanerophyte species. Fifty percent of the native species of the region belong to only 9 families: Asteraceae (277 species), Poaceae (104), Fabaceae (96), Brassicaceae (50), Apiaceae (43), Boraginaceae (42), Portulacaceae (42), Scrophulariaceae, (42) and Solanaceae (40) (Squeo et al. 2001a).

According to the state of conservation categories of the "Red Book of Native Flora and Priority Sites for Conservation: Region of Coquimbo" (Squeo et al., 2001b), 14\% of the native flora are found in the Endangered (36 species) or Vulnerable (171 species) categories. However, the proportion of species in these categories could increase as more becomes known about the species in the categories Insufficiently Known and Non-Evaluated. It is noteworthy that there are 127 species ( $8.6 \%$ of the native regional flora) in the category Insufficiently Known (Extinct), as these species are under suspicion of being extinct. Considering that there are 23 endemic species of the region that are unregistered in the last 50 years, in spite of being one of the regions with a great number of collections in Chile, the number of species currently extinct in the Region of Coquimbo could reach 25 , which is almost $18 \%$ of the endemic flora of the region (Squeo et al., 2001b).
Among the main factors explaining the current state of degradation of the native vegetation are the mining activity of the 19th century (which overexploited the vegetal cover to feed the furnaces), agropecuarian activity, urban expansion and the displacement of the native vegetation by exotic species (Folchi, 2001; Jorquera, 2001; Brown et al., 2003). On the other hand, the human agricultural communities occupying the rural areas of the region have caused significant damage to the ecosystems. These damages include overgrazing (especially from goats), dryland cultivation of steep slopes, and high rates of firewood and vegetal coal consumption as fuel (Brown et al., 2003). This unplanned use of the natural resources causes a reduction in the vegetal cover, which partly explains the decay present in the scenery and the degree of desertification in the region (Lyon, 1991; Novoa and López, 2001). The non-existent communication between these communities facing precarious subsistence conditions and the rest of the country, or even within the same region, is a block to overcoming the problems that these communities are facing. In this context, the generation of environmentally sustainable activities that provide economic benefits is fundamental (Bustamante, 1994).

In addition to providing numerous ecosystemic services and helping to strengthen and expand local economies, biodiversity provides a variety of goods that human beings depend on. Such goods include foods, medicines, fibers, wood, valuable species in floriculture and horticulture, raw materials for numerous industries of economic importance such as the pharmaceutical and textile industries, among others. The flora and fauna species of a region, in turn, impact their ecosystems, in part by determining the very characteristic and frequently unique landscapes, which becomes relevant in economies supported by conventional tourism and ecotourism, as in the case of Chile (Squeo and Arroyo, 2001).

It is possible to confirm that most of the vernacular names of the plants in north and northcentral Chile refer to the natural attributes of the species, including the plant's use. The forage value of several species is illustrated in names 
such as "paja vizcachera" (vizcacha hay) and "pasto de cabra" (goat grass). Medicinal value is expressed in names referring to their properties, such as "pingopingo" (healthy). Other uses are expressed in names such as "candela" or "keri," referring to fuel properties and "paja alma," a ritual plant used in the separation of souls and linked with funeral ceremonies (Romo et al., 1999).

Diverse uses have been traditionally assigned to the native flora of the Region of Coquimbo, where the main beneficiaries are the local communities. For the first American inhabitants of desert and semidesertic zones, cactaceae played an important role in sustenance and in the cultural manifestations of nomadic tribes. They were used as food, drink, medicine, raw material for house construction, elaboration of rustic clothing items (shawls), and the making of hunting and fishing weapons as well as other tools. Cactaceae species acquired such importance that in some cultures they became deities. The use of different parts of cactaceae, living or dead, is scarce in the Region of Coquimbo; they are mostly used for crafts, construction of living fences, firewood and food for cattle (Bustamante, 1996). In the case of chaguales (Puya spp), their dry floral stems were used in light construction, such as roof and wall coating. Chaguales is also used by fishermen to fabricate net floaters (cardones). In addition, ropes can be made with their fibers (Riedemann et al., 2006).

In addition to these traditional uses, numerous changing industries and markets are now generating new demand for products found in the Chilean flora, both directly and indirectly. This is the case for tara (Caesalpinia spinosa Kuntze), which is a legume from which hydrocolloids and tannins are extracted for use in the food, pharmaceutical and cosmetic industries, among others (Pastor et al. 1997). Sesquiterpenes with anticarcinogenic activity against lymphocytic leukemia and human nasopharyngeal carcinoma (Silva and Bittner, 1992) have been identified in mitique (Podanthus ovatifolius Lag.), which is a medicinal plant whose aromatic infusion is recommended for gonorrhea and urinary tract infections (Wilhelm de Mösbach, 1992).
The country has phytogenetic resources of high strategic value in terms of competitiveness and potential for development of new products. Regardless of the above-mentioned uses, the native flora of Chile has still not been systematically searched for bioactive compounds, although it is widely used by local and indigenous communities (León-Lobos et al., 2007).

The species native to the Region of Coquimbo may be used to satisfy various human needs, and they represent a strategic biological resource for the benefit and development of the local communities. However, the number of plants currently used is a small percentage of the total number of known species used in the past. Lack of awareness of the economic and ecological potential of native plants, along with a lack of scientific and technical information, explains why inquires on their cultivation have not been conducted (Lyon, 1991; Montenegro, 2000). Therefore, planting native vegetal species with alternative uses as a component of the rehabilitation of mining tailings could generate a new business for the local communities. Such a business based on non-traditional cultivation of Chilean metallophyte species could benefit and reward small rural villages that have been affected by mining activities while contributing to the sustainability of local mining and the conservation of the native flora.

\section{Native flora of the Region of Coquimbo with potential for phytostabilization programs and alternative uses}

Through a review of the scientific, technical and ethnobotanical literature on the uses traditionally given and possibly given to the native species of the Region of Coquimbo, potential uses of the species spontaneously colonizing deposits of abandoned tailings and of species that, due to their ecological features, might establish and grow in deposits of conditioned tailings through the phytostabilization technology were identified.

Among the 73 native species of the region found colonizing deposits of mining tailings (Ginocchio et al., 2007), 68 (93\%) have at least one use described (Table 1), with the main uses being or- 
namental, forage, medicinal, mellipherous, and chemical (Figure 1). Many of these species have more than one use described for them, with up to nine potential uses as in the case of Echinopsis chiloensis Friedrich et G.D. Rowley, a columnar endemic cactacea of Chile. Among these native tailing deposits colonizing species presenting some additional benefit, the family Asteraceae is the most represented, with 21 species. The most frequent lifestyles are phanerophyte (with 41 species, 11 trees), followed by hemicryptophyte (11 species) and chamaephyte (10 species).

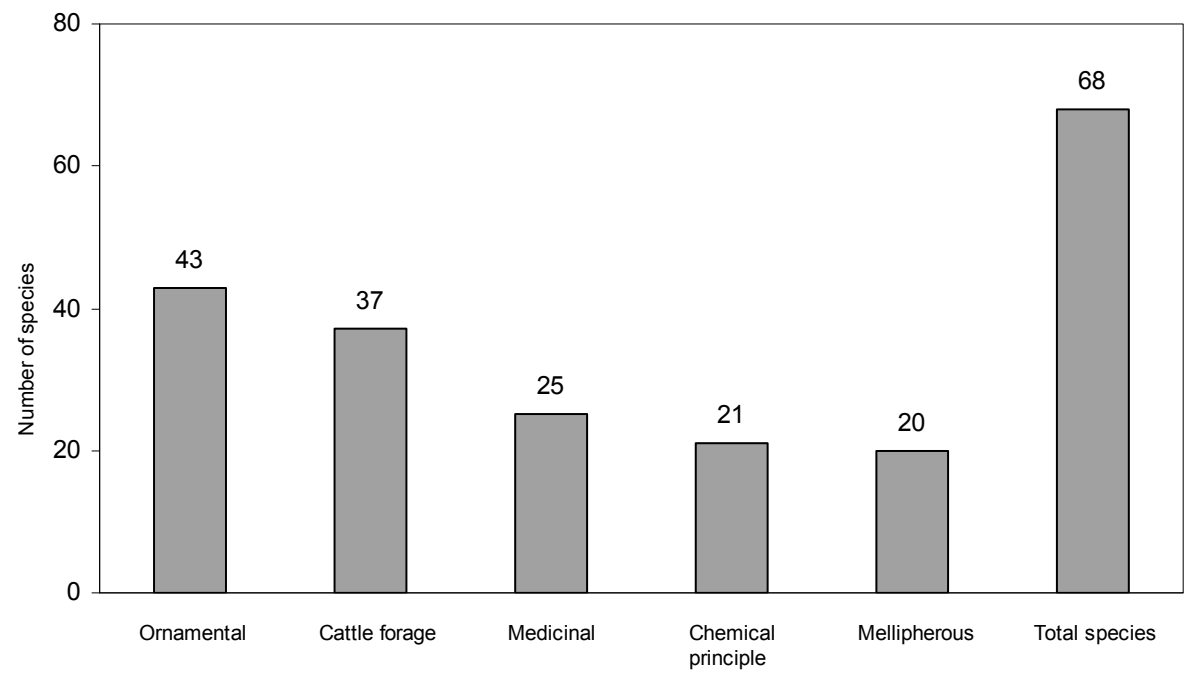

Figure 1. Number of native species of the Coquimbo Region, Chile identified as spontaneous colonizers of abandoned tailing storage facilities and their main uses. Species may have more than one known use. Uses as follow: Alimentary, some of their structures has the property to feed the human; Cattle forage, some of their structures has the property to feed cattle; Medicinal, some of their structures has the power to mitigate a disease in human; Phytochemical, having a substance or active ingredient that alters or modifies the functioning of organs and systems of the human body, which, in turn, can have a medicinal value; Timber/construction, provides raw materials, mainly wood, to build facilities of various kinds, including homes, warehouses or hut; Fuel, used to produce energy as heat, in this case usually wood or coal used to generate heat; Crafts, supply raw materials (fiber, wood, pigments, seeds) for the development works (baskets, hats, figures, etc.) with little intervention of machinery; Soil conservation, its establishment enables the protection of soil resources against physical, chemical and biological degradation; Mellipherous, flora as source of nectar and pollen to Apis melliphera (honeybee); Ornamental, species with the potential to be cultivated for their beauty or their incorporation into green areas.

A search of literature regarding the native flora of the Region of Coquimbo identified 420 species ( $28 \%$ of the native regional flora) with potential for use in mining tailing phytostabilization programs that could provide an additional benefit considering their possible anthropic uses (Table 2). The criteria used to select these vegetal species were their general ecological features, their patterns of adaptability and their relation with other species (such as belonging to the same family). Among the patterns of adaptability, the ability to tolerate high radiation, scarce water and limited nutritional resources were considered. Among the main uses identified for these species are ornamental, mellipherous, forage, medicinal, chemical and artisanal (Figure 2).
Although $62 \%$ of these species have only one use described for them, others have been identified with more than one use, even reaching nine potential uses as in the case of Puya chilensis Molina, an endemic bromeliaceous of Chile. The main families composing this group of species are: Asteraceae (65 species), Cactaceae (30 species), Scrophulariaceae (29 species) and Fabaceae (28 species). On the other hand, the most numerous lifestyle corresponds to phanerophyte (159 species from which 17 correspond to trees), followed by hemicryptophyte ( 83 species) and chamaephyte (63 species).

Ornamental value, which was identified as the main use in both groups of species, may be es- 
Table 1. Native plant species of the Coquimbo Region, Chile spontaneously colonizing tailing storage facilities and their uses.

\begin{tabular}{|c|c|c|c|c|}
\hline Scientific name & Family & Origin $^{1}$ & $\begin{array}{l}\text { Conservation } \\
\text { status }^{2}\end{array}$ & Uses $^{3}$ \\
\hline Acacia caven & Mimosaceae & $\mathrm{N}$ & FP & $2,3,4,5,6,7,9,10$ \\
\hline Adesmia argentea & Papilionaceae & $\mathrm{E}$ & FP & $2,8,9,10$ \\
\hline Adesmia confusa & Papilionaceae & $\mathrm{E}$ & IC (V?) & 2,9 \\
\hline Adesmia microphylla & Papilionaceae & $\mathrm{E}$ & FP & 2,9 \\
\hline Atriplex repanda & Chenopodiaceae & $\mathrm{E}$ & FP & 2 \\
\hline Baccharis linearis & Asteraceae & $\mathrm{N}$ & FP & $2,4,8,10$ \\
\hline Baccharis marginalis & Asteraceae & $\mathrm{E}$ & FP & $3,4,9$ \\
\hline Baccharis pingraea & Asteraceae & $\mathrm{N}$ & FP & $3,4,9$ \\
\hline Bromus berterianus & Poaceae & $\mathrm{N}$ & FP & 1,2 \\
\hline Bromus catharticus & Poaceae & $\mathrm{N}$ & FP & $1,2,3$ \\
\hline Carpobrotus aequilaterus & Aizoaceae & $\mathrm{N}$ & $\mathrm{V}$ & $1,3,10$ \\
\hline Cestrum parqui & Solanaceae & $\mathrm{N}$ & FP & $3,4,6,7$ \\
\hline Chenopodium ambrosioides & Chenopodiaceae & $\mathrm{N}$ & FP & $2,3,4,7$ \\
\hline Chorizanthe glabrescens & Polygonaceae & $\mathrm{E}$ & IC (E?) & 7 \\
\hline Cistanthe arenaria & Portulacaceae & $\mathrm{N}$ & FP & 10 \\
\hline Cordia decandra & Boraginaceae & $\mathrm{E}$ & FP & $1,2,4,6,7,9,10$ \\
\hline Cortaderia rudiuscula & Poaceae & $\mathrm{N}$ & IC (V?) & 10 \\
\hline Cristaria glaucophylla & Malvaceae & $\mathrm{E}$ & FP & 2,10 \\
\hline Distichlis spicata & Poaceae & $\mathrm{N}$ & FP & 2,3 \\
\hline Echinopsis chiloensis & Cactaceae & $\mathrm{E}$ & FP & $1,2,3,4,5,6,7,9,10$ \\
\hline Encelia canescens & Asteraceae & $\mathrm{N}$ & FP & $2,9,10$ \\
\hline Ephedra gracilis & Ephedraceae & $\mathrm{E}$ & FP & $3,4,10$ \\
\hline Equisetum bogotense & Equisetaceae & $\mathrm{N}$ & FP & $3,4,7,10$ \\
\hline Equisetum giganteum & Equisetaceae & $\mathrm{N}$ & FP & 3,10 \\
\hline Frankenia chilensis & Frankeniaceae & $\mathrm{N}$ & FP & 2,10 \\
\hline Gymnophyton robustum & Umbelliferae & $\mathrm{E}$ & FP & 10 \\
\hline Haplopappus angustifolius & Asteraceae & $\mathrm{E}$ & FP & 2,3 \\
\hline Haplopappus bezanillanus & Asteraceae & $\mathrm{E}$ & $\mathrm{V}$ & 2 \\
\hline Haplopappus cerberoanus & Asteraceae & $\mathrm{E}$ & FP & 2 \\
\hline Haplopappus chrysanthemifolius & Asteraceae & $\mathrm{E}$ & $\mathrm{V}$ & 2 \\
\hline Haplopappus macraeanus & Asteraceae & $\mathrm{E}$ & IC (E?) & 2 \\
\hline Haplopappus parvifolius & Asteraceae & $\mathrm{E}$ & FP & 2 \\
\hline Haplopappus reticulatus & Asteraceae & $\mathrm{E}$ & FP & 2 \\
\hline Haplopappus saxatilis & Asteraceae & $\mathrm{E}$ & IC (FP?) & 2 \\
\hline Heliotropium stenophyllum & Boraginaceae & $\mathrm{E}$ & $\mathrm{FP}$ & $2,4,10$ \\
\hline Lithrea caustica & Anacardiaceae & $\mathrm{E}$ & FP & $1,3,4,6,7,8,9$ \\
\hline Lycium chilense & Solanaceae & $\mathrm{N}$ & FP & 10 \\
\hline Malesherbia linearifolia & Malesherbiaceae & $\mathrm{E}$ & FP & 10 \\
\hline Maytenus boaria & Celastraceae & $\mathrm{N}$ & $\mathrm{V}$ & $1,2,3,4,5,7,9,10$ \\
\hline Mentzelia albescens & Loaseceae & $\mathrm{N}$ & FP & 10 \\
\hline Muehlenbeckia hastulata & Polygonaceae & $\mathrm{N}$ & FP & $1,2,3,7,9,10$ \\
\hline Nolana albescens & Nolanaceae & $\mathrm{E}$ & IC (V?) & 10 \\
\hline Nolana crassulifolia & Nolanaceae & $\mathrm{E}$ & $\mathrm{FP}$ & 10 \\
\hline Nolana sedifolia & Nolanaceae & $\mathrm{E}$ & FP & 10 \\
\hline Ophryosporus paradoxus & Asteraceae & $\mathrm{E}$ & FP & 10 \\
\hline Ophryosporus triangularis & Asteraceae & $\mathrm{E}$ & FP & 10 \\
\hline Otholobium glandulosum & Papilionaceae & $\mathrm{N}$ & FP & 1,10 \\
\hline Plantago hispidula & Plantaginaceae & $\mathrm{E}$ & FP & 2 \\
\hline Pleocarphus revolutus & Asteraceae & $\mathrm{E}$ & FP & $3,4,10$ \\
\hline Polypogon australis & Poaceae & $\mathrm{N}$ & FP & 2 \\
\hline Prosopis chilensis & Mimosaceae & $\mathrm{N}$ & $\mathrm{V}$ & $1,2,5,6,7,8,9,10$ \\
\hline Proustia ilicifolia & Asteraceae & $\mathrm{E}$ & FP & $3,4,5,8,10$ \\
\hline Quillaja saponaria & Rosaceae & $\mathrm{E}$ & $\mathrm{V}$ & $3,4,5,9,10$ \\
\hline Salix humboldtiana & Salicaceae & $\mathrm{N}$ & FP & $2,3,7,10$ \\
\hline Sarcocornia fruticosa & Chenopodiaceae & $\mathrm{N}$ & FP & 10 \\
\hline Schinus latifolia & Anacardiaceae & $\mathrm{E}$ & FP & $1,2,3,4,5,7,9,10$ \\
\hline Schinus molle & Anacardiaceae & $\mathrm{N}$ & FP & $3,4,5,6,7,10$ \\
\hline Schinus polygama & Anacardiaceae & $\mathrm{N}$ & FP & $1,2,3,4,5,7,10$ \\
\hline Scirpus asper & Cyperaceae & $\mathrm{N}$ & FP & $2,5,7$ \\
\hline Scirpus pungens & Cyperaceae & $\mathrm{N}$ & $\mathrm{V}$ & 2 \\
\hline Senecio adenotrichius & Asteraceae & $\mathrm{E}$ & FP & 9,10 \\
\hline Senecio bridgesii & Asteraceae & $\mathrm{E}$ & FP & 9,10 \\
\hline Senecio cerberoanus & Asteraceae & $\mathrm{E}$ & $\mathrm{V}$ & 9,10 \\
\hline Senecio murinus & Asteraceae & $\mathrm{E}$ & FP & 9,10 \\
\hline Senna cumingii & Caesalpiniaceae & $\mathrm{E}$ & FP & $2,7,9,10$ \\
\hline Solanum pinnatum & Solanaceae & $\mathrm{E}$ & FP & 4,10 \\
\hline Tessaria absinthioides & Asteraceae & $\mathrm{N}$ & FP & $1,2,3,4,5,10$ \\
\hline Typha angustifolia & Typhaceae & $\mathrm{N}$ & FP & $2,3,5,7$ \\
\hline
\end{tabular}

${ }^{1}$ E, endemic to Chile, $\mathrm{N}$ : native to Chile.

${ }^{2} \mathrm{FP}$, out of danger, IC(E?): insufficiently known (extinct?), IC(FP?): insufficiently known (out of danger?), IC(V?): insufficiently known (vulnerable?), V: vulnerable

${ }^{3}$ 1: alimentary, 2: cattle forage, 3: medicinal, 4: phytochemical, 5: timber/construction, 6: fuel, 7: crafts, 8: soil conservation, 9: mellipherous, 10: ornamental. 


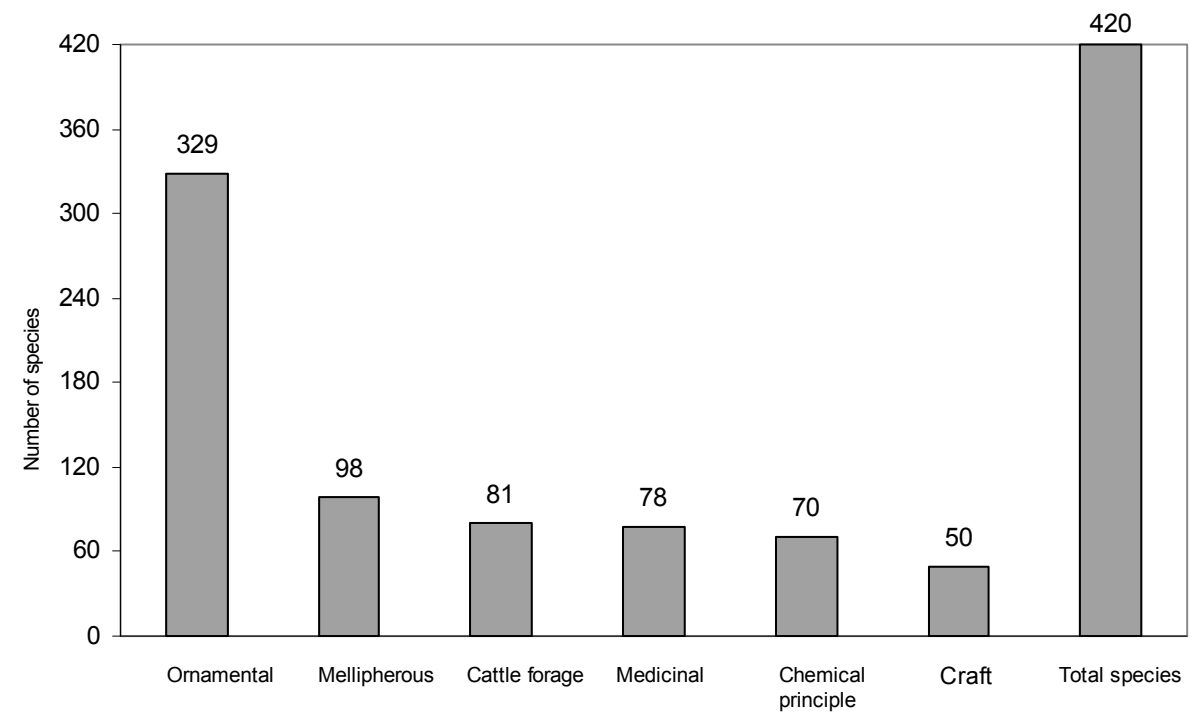

Figure 2. Number of native species of the Coquimbo Region, Chile, with potential for use in tailing storage facility phytostabilization projects according to their known primary uses. Species may have more than one known use. Uses as follow: Alimentary, some of their structures has the property to feed the human; Cattle forage, some of their structures has the property to feed cattle; Medicinal, some of their structures has the power to mitigate a disease in human; Phytochemical, having a substance or active ingredient that alters or modifies the functioning of organs and systems of the human body, which, in turn, can have a medicinal value; Timber/construction, provides raw materials, mainly wood, to build facilities of various kinds, including homes, warehouses or hut; Fuel, used to produce energy as heat, in this case usually wood or coal used to generate heat; Crafts, supply raw materials (fiber, wood, pigments, seeds) for the development works (baskets, hats, figures, etc.) with little intervention of machinery; Soil conservation, its establishment enables the protection of soil resources against physical, chemical and biological degradation; Mellipherous, flora as source of nectar and pollen to Apis melliphera (honeybee); Ornamental, species with the potential to be cultivated for their beauty or their incorporation into green areas.

timated when these species are cultivated for commercial purposes or are incorporated into projects of public and private spaces. Species of ornamental value could certainly embellish the vegetal community developing on mining tailing deposits, but if the landscape esthetics are not valued, this would be useless, unless the individuals are transplanted to places where they are really appreciated, which would damage the stabilization of the mentioned substrate. On the other hand, for many of the species identified with an ornamental use, this relates to their flowering. It is noteworthy that the plants growing in adverse conditions possibly do not flower due to the high concentrations of metals and the lack of essential nutrients for the development of reproductive structures. Excluding ornamental use as an additional benefit, the number native species found spontaneously colonizing abandoned tailing storage facilities with some additional use is 56 , or $77 \%$ of the registered species. On the other hand, the number of native species not growing in tailing deposits but (due to their ecological aspects) potentially usable in phytostabilization programs that present interesting additional uses is 237 , or $16 \%$ of the native regional flora.

Among the uses identified, some of these demand direct intake of vegetal structures by human beings or animals, as with food, medicine and forage. Bearing in mind that the species growing in deposits of mining tailings could mobilize metals towards aerial structures to be consumed, thereby generating toxic effects on other living beings and introducing contaminants into the food chain (Berti and Cunningham, 2000; Ginocchio, 2004), it is essential that the vertical movement of metals in the species to be included in phytostabilization programs be evaluated. This consideration is also applicable in the case of the mellipherous use, considering 
that nectar may be a way for metals to enter the beehive, and therefore a source of honey contamination (Fernández et al., 1994).

Special attention was paid to species described in the reviewed literature as relevant to soil conservation as that could grow on degraded terrains and help retain soil. In total, 28 species have been identified for replanting degraded terrains, mainly phanerophytes. For example, cactaceae are an excellent means of soil protection due to their wide and superficial radical systems, their adaptability to thin and degraded soils, and their resistance to climatic factors (Bustamante, 1996). On the other hand, species belonging to the Fabales order are also noteworthy because of their ability to fix atmospheric nitrogen through a symbiosis with bacteria of the genus Rhizobium. Among the species found colonizing deposits of mining tailings with additional uses, three species of the order Fabales are found (one of the Caesalpiniaceae family and two of the Mimosaceae family; Table 1). Among the species with potential for phytostabilization and with uses described in the literature, 35 species of the Fabales order are found (four of the Caesalpiniaceae family, 28 of the Fabaceae family and three of the Mimosaceae family; Table 2). Due to scarce nitrogen in tailings, these species could be crucial to the generation of functional and autosustainable ecosystems for the phytostabilization of post-operative tailing deposits. It is noteworthy that species belonging to the genera Acacia and Prosopis have been reported to be successful colonizers of mining tailings in the western United States (Mendez and Maier, 2008).

As in the case of species spontaneously colonizing abandoned tailing deposits, among the species with potential for phytostabilization programs and with identified uses, the family Asteraceae is the most represented. Coincidently, this family is the most numerous in the native flora of the Region of Coquimbo. Therefore, it is impossible to infer that the Asteraceae family gathers species that are more rustic, plastic or tolerant to metals, nor that the species of this family are the most used.

On the other hand, in both groups of species (species found on tailings and species with po- tential for phytostabilization programs), phanerophytes are the most represented life form. This fact becomes relevant when considering which tree and bush-like species could simplify the management of an ecological rehabilitation site, as these are perennial species not requiring annual germination like terophyte species. It is not impossible that species able to grow in managed mining tailings could not generate viable seeds, or that germination is hindered when facing adverse tailing conditions. In any case, planting other life forms, which is essential in successional processes, represents a fundamental aspect of successful phytostabilization of post-operative tailing deposits.

Among the native species spontaneously colonizing tailing deposits presenting some additional benefit, $56 \%$ (38 species) are endemic to Chile (Marticorena et al., 2001), which is relevant as they are a valuable genetic resource for relieving environmental problems related to the mining sector, and they could be lost if they are not identified or studied in time (Ginocchio and Baker, 2004). Only two of these are endemic to the Region of Coquimbo; Haplopappus bezanillanus Reiche and Chorizanthe glabrescens Benth. However, ecotypes from the remaining 36 endemic species (as well as from the other native species) able to tolerate high metal concentrations could have possibly developed in the region, and they could be absent in other regions of the country. It is worth highlighting the high percentage of endemism among the species with potential for phytostabilization programs identified by their ecological aspects. Seventy-one percent (297 species) are endemic to Chile, and $33 \%$ are endemic to the region (Marticorena et al. 2001). As with the species spontaneously colonizing abandoned tailing deposits, these species are a unique resource for the country (and the region), with ecological features and identified uses that make them a valuable resource for phytostabilization programs. Therefore, there is an urgent need for further studies.

Most of the species growing in tailing storage facilities with identified uses are not endangered, with eight species in the category of vulnerable and six insufficiently known (Table 1). In the case of the species that, according to their ecological features, could grow in managed tail- 
Table 2. Native plant species of the Coquimbo Region, Chile with potential for use in mine tailing storage facility phytostabilization projects and their uses

\begin{tabular}{|c|c|c|c|c|}
\hline Scientific name & Family & Origin $^{1}$ & Conservation status $^{2}$ & Uses $^{3}$ \\
\hline Adenopeltis serrata & Euphorbiaceae & $\bar{E}$ & $\mathrm{~V}$ & $3,8,10$ \\
\hline Adesmia bedwellii & Fabaceae & $\mathrm{E}$ & $\mathrm{FP}$ & $2,5,8,9,10$ \\
\hline Adesmia littoralis & Fabaceae & $\mathrm{E}$ & EP & $2,8,9,10$ \\
\hline Alona coelestis & Nolanaceae & $\mathrm{E}$ & $\mathrm{FP}$ & 4 \\
\hline Alona filifolia & Nolanaceae & $\mathrm{E}$ & FP & 4 \\
\hline Alona rostrata & Nolanaceae & $\mathrm{E}$ & FP & 4 \\
\hline Alonsoa meridionalis & Scrophulariaceae & $\mathrm{N}$ & FP & 10 \\
\hline Alstroemeria angustifolia & Alstroemeriaceae & $\mathrm{E}$ & IC (EP?) & 10 \\
\hline Alstroemeria crispata & Alstroemeriaceae & $\mathrm{E}$ & FP & 10 \\
\hline Alstroemeria diluta & Alstroemeriaceae & $\mathrm{E}$ & FP & 10 \\
\hline Alstroemeria hookeri & Alstroemeriaceae & $\mathrm{E}$ & $\mathrm{V}$ & 10 \\
\hline Alstroemeria kingii & Alstroemeriaceae & $\mathrm{E}$ & FP & 10 \\
\hline Alstroemeria leporina & Alstroemeriaceae & $\mathrm{E}$ & $\mathrm{V}$ & 10 \\
\hline Alstroemeria magenta & Alstroemeriaceae & $\mathrm{E}$ & FP & 10 \\
\hline Alstroemeria magna & Alstroemeriaceae & $\mathrm{E}$ & IC (V?) & 10 \\
\hline Alstroemeria magnifica & Alstroemeriaceae & $\mathrm{E}$ & FP & 10 \\
\hline Alstroemeria modesta & Alstroemeriaceae & $\mathrm{E}$ & IC (V?) & 10 \\
\hline Alstroemeria pallida & Alstroemeriaceae & $\mathrm{E}$ & IC (FP?) & 10 \\
\hline Alstroemeria pelegrina & Alstroemeriaceae & $\mathrm{N}$ & $\mathrm{V}$ & 10 \\
\hline Alstroemeria pulchra & Alstroemeriaceae & $\mathrm{E}$ & IC (V?) & 10 \\
\hline Alstroemeria schizanthoides & Alstroemeriaceae & $\mathrm{E}$ & FP & 10 \\
\hline Alstroemeria spathulata & Alstroemeriaceae & $\mathrm{E}$ & IC (V?) & 10 \\
\hline Alstroemeria spectabilis & Alstroemeriaceae & $\mathrm{E}$ & IC & 10 \\
\hline Alstroemeria umbellata & Alstroemeriaceae & $\mathrm{E}$ & IC (E?) & 10 \\
\hline Alstroemeria werdemnnii & Alstroemeriaceae & $\mathrm{E}$ & IC & 10 \\
\hline Anisomeria coriacea & Phytolaccaceae & $\mathrm{E}$ & $\mathrm{V}$ & $3,4,10$ \\
\hline Anisomeria littoralis & Phytolaccaceae & $\mathrm{E}$ & $\mathrm{FP}$ & 10 \\
\hline Argemone hunnemannii & Papaveraceae & $\mathrm{N}$ & FP & 10 \\
\hline Argemone rosea & Papaveraceae & $\mathrm{E}$ & FP & 10 \\
\hline Argemone subfusiformis & Papaveraceae & $\mathrm{N}$ & FP & 3,10 \\
\hline Argylia adscendens & Bignoniaceae & $\mathrm{E}$ & FP & 3,4 \\
\hline Argylia farnesiana & Bignoniaceae & $\mathrm{E}$ & IC (V?) & 4 \\
\hline Argylia geranioides & Bignoniaceae & $\mathrm{E}$ & FP & 4 \\
\hline Argylia potentillifolia & Bignoniaceae & $\mathrm{E}$ & $\mathrm{FP}$ & 4 \\
\hline Argylia radiata & Bignoniaceae & $\mathrm{N}$ & FP & $3,4,10$ \\
\hline Aristolochia bridgesii & Aristolochiaceae & $\mathrm{E}$ & FP & 3,10 \\
\hline Aristolochia chilensis & Aristolochiaceae & $\mathrm{E}$ & FP & $3,4,10$ \\
\hline Armeria maritima & Plumbaginaceae & $\mathrm{N}$ & $\mathrm{V}$ & 10 \\
\hline Astephanus geminiflorus & Asclepiadaceae & $\mathrm{E}$ & FP & 3,10 \\
\hline Astragalus amatus & Fabaceae & $\mathrm{E}$ & $\mathrm{V}$ & 9 \\
\hline Astragalus arnottianus & Fabaceae & $\mathrm{N}$ & FP & 9 \\
\hline Astragalus bellus & Fabaceae & $\mathrm{N}$ & IC (E?) & 9 \\
\hline Astragalus berterianus & Fabaceae & $\mathrm{E}$ & IC (FP?) & 9 \\
\hline Astragalus berteroi & Fabaceae & $\mathrm{E}$ & IC (V?) & 9 \\
\hline Astragalus bustillosii & Fabaceae & $\mathrm{N}$ & $\mathrm{FP}$ & 9 \\
\hline Astragalus chamissonis & Fabaceae & $\mathrm{N}$ & IC (FP?) & 9 \\
\hline Astragalus coquimbensis & Fabaceae & $\mathrm{E}$ & IC (FP?) & 9 \\
\hline Astragalus cruckshanksii & Fabaceae & $\mathrm{N}$ & FP & 9 \\
\hline Astragalus curvicaulis & Fabaceae & $\mathrm{E}$ & IC (E?) & 9 \\
\hline Astragalus dodtii & Fabaceae & $\mathrm{E}$ & IC (E?) & 9 \\
\hline Astragalus edmonstonei & Fabaceae & $\mathrm{E}$ & IC (V?) & 9 \\
\hline Astragalus limariensis & Fabaceae & $\mathrm{E}$ & FP & 9 \\
\hline Astragalus looseri & Fabaceae & $\mathrm{N}$ & FP & 9 \\
\hline Astragalus nudus & Fabaceae & $\mathrm{E}$ & FP & 9 \\
\hline
\end{tabular}




\begin{tabular}{|c|c|c|c|c|}
\hline Scientific name & Family & Origin $^{1}$ & Conservation status $^{2}$ & Uses $^{3}$ \\
\hline Astragalus paposanus & Fabaceae & $E$ & IC (E?) & 9 \\
\hline Astragalus pehuenches & Fabaceae & $\mathrm{N}$ & IC (E?) & 9 \\
\hline Astragalus pissisii & Fabaceae & $\mathrm{E}$ & IC & 9 \\
\hline Astragalus schinetorum & Fabaceae & $\mathrm{E}$ & IC (EP?) & 9 \\
\hline Astragalus vagus & Fabaceae & $\mathrm{N}$ & IC (V?) & 9 \\
\hline Astragalus vesiculosus & Fabaceae & $\mathrm{N}$ & FP & 9 \\
\hline Atriplex coquimbana & Chenopodiaceae & $\mathrm{E}$ & EP & 2 \\
\hline Atriplex costellata & Chenopodiaceae & $\mathrm{E}$ & IC & 2 \\
\hline Atriplex deserticola & Chenopodiaceae & $\mathrm{N}$ & $\mathrm{FP}$ & $2,8,10$ \\
\hline Atriplex leuca & Chenopodiaceae & $\mathrm{E}$ & $\mathrm{NE}$ & 2 \\
\hline Atriplex mucronata & Chenopodiaceae & $\mathrm{E}$ & IC & 2 \\
\hline Atriplex oreophila & Chenopodiaceae & $\mathrm{N}$ & FP & 2 \\
\hline Atriplex vallenarensis & Chenopodiaceae & $\mathrm{E}$ & IC (E?) & 2 \\
\hline Azara celastrina & Flacourtiaceae & $\mathrm{E}$ & $\mathrm{V}$ & $5,9,10$ \\
\hline Azara dentata & Flacourtiaceae & $\mathrm{E}$ & IC (V?) & $4,5,9,10$ \\
\hline Azara petiolaris & Flacourtiaceae & $\mathrm{E}$ & FP & $5,9,10$ \\
\hline Azara serrata & Flacourtiaceae & $\mathrm{E}$ & IC & $5,9,10$ \\
\hline Baccharis confertifolia & Asteraceae & $\mathrm{E}$ & FP & 4,7 \\
\hline Baccharis juncea & Asteraceae & $\mathrm{N}$ & FP & 2 \\
\hline Baccharis macraei & Asteraceae & $\mathrm{E}$ & IC (V?) & 4 \\
\hline Baccharis paniculata & Asteraceae & $\mathrm{E}$ & FP & 4 \\
\hline Baccharis rhomboidalis & Asteraceae & $\mathrm{N}$ & IC & 4 \\
\hline Baccharis salicifolia & Asteraceae & $\mathrm{N}$ & $\mathrm{FP}$ & 10 \\
\hline Bahia ambrosioides & Asteraceae & $\mathrm{E}$ & FP & $2,3,4,9,10$ \\
\hline Balsamocarpon brevifolium & Caesalpiniaceae & $\mathrm{E}$ & EP & $3,4,7,10$ \\
\hline Berberis actinacantha & Berberidaceae & $\mathrm{E}$ & FP & $1,4,7,10$ \\
\hline Berberis chilensis & Berberidaceae & $\mathrm{E}$ & FP & $1,4,7,10$ \\
\hline Berberis empetrifolia & Berberidaceae & $\mathrm{N}$ & FP & $1,4,7,10$ \\
\hline Berberis glomerata & Berberidaceae & $\mathrm{E}$ & FP & $1,4,7,10$ \\
\hline Bromus cebadilla & Poaceae & $\mathrm{N}$ & FP & 2 \\
\hline Bromus setifolius & Poaceae & $\mathrm{N}$ & FP & 2 \\
\hline Buddleja globosa & Buddlejaceae & $\mathrm{N}$ & FP & $3,4,7,10$ \\
\hline Bulnesia chilensis & Zygophyllaceae & $\mathrm{E}$ & FP & $7,8,10$ \\
\hline Caesalpinia angulata & Caesalpiniaceae & $\mathrm{E}$ & $\mathrm{V}$ & $3,8,10$ \\
\hline Caesalpinia spinosa & Caesalpiniaceae & $\mathrm{N}$ & EP & $1,2,3,4,5,7,8,10$ \\
\hline Calandrinia cachinalensis & Portulacaceae & $\mathrm{E}$ & FP & 10 \\
\hline Calandrinia lamprosperma & Portulacaceae & $\mathrm{E}$ & IC & 10 \\
\hline Calandrinia litoralis & Portulacaceae & $\mathrm{E}$ & $\mathrm{V}$ & 3,10 \\
\hline Calceolaria abscondita & Scrophulariaceae & $\mathrm{E}$ & IC (V?) & 10 \\
\hline Calceolaria ambigua & Scrophulariaceae & $\mathrm{E}$ & IC (V?) & 10 \\
\hline Calceolaria andina & Scrophulariaceae & $\mathrm{E}$ & $\mathrm{FP}$ & 10 \\
\hline Calceolaria arachnoidea & Scrophulariaceae & $\mathrm{E}$ & FP & 7,10 \\
\hline Calceolaria biflora & Scrophulariaceae & $\mathrm{N}$ & FP & 10 \\
\hline Calceolaria cana & Scrophulariaceae & $\mathrm{E}$ & FP & 10 \\
\hline Calceolaria collina & Scrophulariaceae & $\mathrm{E}$ & IC (E?) & 10 \\
\hline Calceolaria corymbosa & Scrophulariaceae & $\mathrm{E}$ & $\mathrm{V}$ & 9,10 \\
\hline Calceolaria densifolia & Scrophulariaceae & $\mathrm{E}$ & IC (E?) & 10 \\
\hline Calceolaria filicaulis & Scrophulariaceae & $\mathrm{N}$ & $\mathrm{NE}$ & 10 \\
\hline Calceolaria glandulifera & Scrophulariaceae & $\mathrm{E}$ & $\mathrm{V}$ & 10 \\
\hline Calceolaria glandulosa & Scrophulariaceae & $\mathrm{E}$ & FP & 4,10 \\
\hline Calceolaria hypericina & Scrophulariaceae & $\mathrm{N}$ & FP & 4,10 \\
\hline Calceolaria integrifolia & Scrophulariaceae & $\mathrm{N}$ & $\mathrm{FP}$ & 10 \\
\hline Calceolaria kingii & Scrophulariaceae & $\mathrm{E}$ & IC (V?) & 4,10 \\
\hline Calceolaria latifolia & Scrophulariaceae & $\mathrm{E}$ & IC (E?) & 4,10 \\
\hline Calceolaria lepida & Scrophulariaceae & $\mathrm{E}$ & FP & 4,10 \\
\hline Calceolaria montana & Scrophulariaceae & $\mathrm{N}$ & IC (V?) & 10 \\
\hline
\end{tabular}




\begin{tabular}{|c|c|c|c|c|}
\hline Scientific name & Family & Origin $^{1}$ & Conservation status $^{2}$ & Uses $^{3}$ \\
\hline Calceolaria morisii & Scrophulariaceae & $\mathrm{E}$ & $\mathrm{V}$ & 10 \\
\hline Calceolaria paposana & Scrophulariaceae & $\mathrm{E}$ & IC & 10 \\
\hline Calceolaria petioalaris & Scrophulariaceae & $\mathrm{E}$ & $\mathrm{FP}$ & 10 \\
\hline Calceolaria picta & Scrophulariaceae & $\mathrm{E}$ & EP & 10 \\
\hline Calceolaria pinifolia & Scrophulariaceae & $\mathrm{N}$ & FP & 10 \\
\hline Calceolaria polifolia & Scrophulariaceae & $\mathrm{E}$ & FP & 4,10 \\
\hline Calceolaria pubescens & Scrophulariaceae & $\mathrm{E}$ & IC (E?) & 10 \\
\hline Calceolaria quadriradiata & Scrophulariaceae & $\mathrm{E}$ & IC (E?) & 10 \\
\hline Calceolaria robusta & Scrophulariaceae & $\mathrm{E}$ & $\mathrm{EP}$ & 10 \\
\hline Calliandra chilensis & Mimosaceae & $\mathrm{E}$ & FP & 10 \\
\hline Calydorea xiphioides & Iridaceae & $\mathrm{E}$ & IC (FP?) & 1,10 \\
\hline Centaurea cachinalensis & Asteraceae & $\mathrm{E}$ & $\mathrm{FP}$ & $3,4,9,10$ \\
\hline Centaurea chilensis & Asteraceae & $\mathrm{E}$ & FP & $2,3,4,9,10$ \\
\hline Centaurea floccosa & Asteraceae & $\mathrm{E}$ & $\mathrm{V}$ & $2,3,4,9,10$ \\
\hline Chaetanthera chilensis & Asteraceae & $\mathrm{E}$ & IC (V?) & 10 \\
\hline Chaetanthera glabrata & Asteraceae & $\mathrm{E}$ & FP & 10 \\
\hline Chaetanthera microphylla & Asteraceae & $\mathrm{N}$ & $\mathrm{V}$ & 10 \\
\hline Chenopodium chilense & Chenopodiaceae & $\mathrm{N}$ & IC (V?) & 3 \\
\hline Chenopodium frigidum & Chenopodiaceae & $\mathrm{N}$ & FP & 3 \\
\hline Chenopodium macrospermum & Chenopodiaceae & $\mathrm{N}$ & IC (E?) & 3 \\
\hline Chenopodium petiolare & Chenopodiaceae & $\mathrm{N}$ & $\mathrm{FP}$ & 3 \\
\hline Chorizanthe commissuralis & Polygonaceae & $\mathrm{N}$ & FP & 7 \\
\hline Chorizanthe dasyantha & Polygonaceae & $\mathrm{E}$ & IC (E?) & 7 \\
\hline Chorizanthe frankenioides & Polygonaceae & $\mathrm{E}$ & $\mathrm{EP}$ & 7 \\
\hline Chorizanthe kingii & Polygonaceae & $\mathrm{E}$ & $\mathrm{V}$ & 7 \\
\hline Chorizanthe paniculata & Polygonaceae & $\mathrm{E}$ & $\mathrm{V}$ & 7 \\
\hline Chorizanthe peduncularis & Polygonaceae & $\mathrm{E}$ & $\mathrm{V}$ & 7 \\
\hline Chorizanthe vaginata & Polygonaceae & $\mathrm{E}$ & IC (E?) & $3,7,10$ \\
\hline Chorizanthe viridis & Polygonaceae & $\mathrm{E}$ & FP & 7 \\
\hline Chuquiraga oppositifolia & Asteraceae & $\mathrm{N}$ & FP & 2,10 \\
\hline Chuquiraga ulicina & Asteraceae & $\mathrm{E}$ & $\mathrm{FP}$ & 10 \\
\hline Cissus striata & Vitaceae & $\mathrm{N}$ & $\mathrm{FP}$ & $3,5,10$ \\
\hline Cistanthe amarantoides & Portulacaceae & $\mathrm{E}$ & $\mathrm{IC}$ & 10 \\
\hline Cistanthe coquimbensis & Portulacaceae & $\mathrm{E}$ & FP & 10 \\
\hline Cistanthe grandiflora & Portulacaceae & $\mathrm{E}$ & $\mathrm{FP}$ & 3,10 \\
\hline Cistanthe longiscapa & Portulacaceae & $\mathrm{E}$ & $\mathrm{FP}$ & 10 \\
\hline Cistanthe salsoloides & Portulacaceae & $\mathrm{N}$ & FP & 10 \\
\hline Clarkia tenella & Onagraceae & $\mathrm{N}$ & $\mathrm{FP}$ & 10 \\
\hline Colletia hystrix & Rhamnaceae & $\mathrm{N}$ & $\mathrm{FP}$ & 4,10 \\
\hline Colletia ulicina & Rhamnaceae & $\mathrm{E}$ & $\mathrm{NE}$ & 10 \\
\hline Colliguaja dombeyana & Euphorbiaceae & $\mathrm{E}$ & FP & 2,3 \\
\hline Colliguaja integerrima & Euphorbiaceae & $\mathrm{N}$ & $\mathrm{FP}$ & $2,3,7,8,9$ \\
\hline Colliguaja odorifera & Euphorbiaceae & $\mathrm{E}$ & FP & $2,3,7,8,9,10$ \\
\hline Colliguaja salicifolia & Euphorbiaceae & $\mathrm{E}$ & IC (FP?) & $2,3,7,8,9$ \\
\hline Convolvulus chilensis & Convolvulaceae & $\mathrm{E}$ & $\mathrm{FP}$ & 2 \\
\hline Copiapoa coquimbana & Cactaceae & $\mathrm{E}$ & $\mathrm{FP}$ & 9,10 \\
\hline Copiapoa pendulina & Cactaceae & $\mathrm{E}$ & IC (E?) & 9,10 \\
\hline Copiapoa pseudocoquimbana & Cactaceae & $\mathrm{E}$ & IC & 9,10 \\
\hline Cristaria argyliifolia & Malvaceae & $\mathrm{E}$ & IC & 10 \\
\hline Cristaria aspera & Malvaceae & $\mathrm{E}$ & $\mathrm{V}$ & 10 \\
\hline Cristaria cyanea & Malvaceae & $\mathrm{E}$ & IC & 10 \\
\hline Cristaria dissecta & Malvaceae & $\mathrm{N}$ & FP & 10 \\
\hline Cristaria gracilis & Malvaceae & $\mathrm{E}$ & IC & 10 \\
\hline Cristaria multiflora & Malvaceae & $\mathrm{E}$ & FP & 10 \\
\hline Cruckshanksia hymenodon & Rubiaceae & $\mathrm{N}$ & $\mathrm{FP}$ & 10 \\
\hline Cruckshanksia montiana & Rubiaceae & $\mathrm{E}$ & $\mathrm{V}$ & 10 \\
\hline
\end{tabular}




\begin{tabular}{|c|c|c|c|c|}
\hline Scientific name & Family & Origin $^{1}$ & Conservation status $^{2}$ & Uses $^{3}$ \\
\hline Cruckshanksia pumila & Rubiaceae & $E$ & FP & 10 \\
\hline Cuscuta chilensis & Cuscutaceae & $\mathrm{N}$ & FP & 3,9 \\
\hline Cynanchum boerhaviifolium & Asclepiadaceae & $\mathrm{E}$ & FP & 10 \\
\hline Cynanchum viride & Asclepiadaceae & $\mathrm{E}$ & $\mathrm{FP}$ & 10 \\
\hline Dinemagonum gayanum & Malpighiaceae & $\mathrm{E}$ & $\mathrm{V}$ & 10 \\
\hline Dioscorea bryoniifolia & Dioscoreaceae & $\mathrm{E}$ & $\mathrm{V}$ & 10 \\
\hline Dioscorea fastigiata & Dioscoreaceae & $\mathrm{E}$ & IC & $1,4,10$ \\
\hline Diostea juncea & Verbenaceae & $\mathrm{N}$ & IC (FP?) & 10 \\
\hline Diplolepis menziesii & Asclepiadaceae & $\mathrm{E}$ & IC (V?) & 10 \\
\hline Dodonaea viscosa & Sapindaceae & $\mathrm{N}$ & $\mathrm{V}$ & 3,10 \\
\hline Echinopsis coquimbana & Cactaceae & $\mathrm{E}$ & FP & $1,3,5,6,7,9,10$ \\
\hline Echinopsis litoralis & Cactaceae & $\mathrm{E}$ & $\mathrm{V}$ & $1,3,5,6,9,10$ \\
\hline Echinopsis nigripilis & Cactaceae & $\mathrm{E}$ & IC (E?) & $3,5,6,9,10$ \\
\hline Echinopsis skottsbergii & Cactaceae & $\mathrm{E}$ & FP & $2,3,4,5,6,9,10$ \\
\hline Echinopsis spinibarbis & Cactaceae & $\mathrm{E}$ & IC (EP?) & $3,5,6,9,10$ \\
\hline Ephedra breana & Ephedraceae & $\mathrm{N}$ & $\mathrm{FP}$ & $1,2,3,6,8,10$ \\
\hline Ephedra chilensis & Ephedraceae & $\mathrm{N}$ & FP & 10 \\
\hline Erigeron fasciculatus & Asteraceae & $\mathrm{E}$ & $\mathrm{V}$ & 2 \\
\hline Eriosyce aurata & Cactaceae & $\mathrm{E}$ & $\mathrm{V}$ & 9,10 \\
\hline Eriosyce chilensis & Cactaceae & $\mathrm{E}$ & $\mathrm{V}$ & 9,10 \\
\hline Eriosyce curvispina & Cactaceae & $\mathrm{E}$ & FP & 9,10 \\
\hline Eriosyce heinrichiana & Cactaceae & $\mathrm{E}$ & $\mathrm{V}$ & 9,10 \\
\hline Eriosyce ihotzkyana & Cactaceae & $\mathrm{E}$ & IC & 9,10 \\
\hline Eriosyce kunzei & Cactaceae & $\mathrm{E}$ & EP & 9,10 \\
\hline Eriosyce lapampaensis & Cactaceae & $\mathrm{E}$ & IC & 9,10 \\
\hline Eriosyce limariensis & Cactaceae & $\mathrm{E}$ & IC (V?) & 9,10 \\
\hline Eriosyce senilis & Cactaceae & $\mathrm{E}$ & IC (V?) & 9,10 \\
\hline Eriosyce subgibbosa & Cactaceae & $\mathrm{E}$ & FP & 9,10 \\
\hline Eriosyce tenebrica & Cactaceae & $\mathrm{E}$ & IC (V?) & 9,10 \\
\hline Eriosyce villosa & Cactaceae & $\mathrm{E}$ & IC (V?) & 9,10 \\
\hline Errazurizia multifoliolata & Fabaceae & $\mathrm{E}$ & FP & 10 \\
\hline Eryngium paniculatum & Apiaceae & $\mathrm{N}$ & FP & 8,10 \\
\hline Escallonia pulverulenta & Escalloniaceae & $\mathrm{E}$ & FP & $3,5,9,10$ \\
\hline Eulychnia acida & Cactaceae & $\mathrm{E}$ & $\mathrm{FP}$ & $1,2,3,5,6,7,9,10$ \\
\hline Eulychnia breviflora & Cactaceae & $\mathrm{E}$ & EP & $2,5,6,7,9,10$ \\
\hline Eulychnia castanea & Cactaceae & $\mathrm{E}$ & FP & $1,5,9,10$ \\
\hline Fabiana imbricata & Solanaceae & $\mathrm{N}$ & FP & $3,4,10$ \\
\hline Fabiana viscosa & Solanaceae & $\mathrm{E}$ & FP & $2,3,10$ \\
\hline Fagonia chilensis & Zygophyllaceae & $\mathrm{N}$ & FP & 10 \\
\hline Flourensia thurifera & Asteraceae & $\mathrm{E}$ & FP & 2,10 \\
\hline Fuchsia lycioides & Onagraceae & $\mathrm{E}$ & $\mathrm{FP}$ & $2,3,7,9,10$ \\
\hline Geoffroea decorticans & Fabaceae & $\mathrm{N}$ & $\mathrm{V}$ & $1,3,5,7,9,10$ \\
\hline Geranium core-core & Geraniaceae & $\mathrm{N}$ & FP & $3,9,10$ \\
\hline Glandularia origenes & Verbenaceae & $\mathrm{N}$ & FP & 3 \\
\hline Glandularia porrigens & Verbenaceae & $\mathrm{E}$ & IC (V?) & 10 \\
\hline Glandularia sulphurea & Verbenaceae & $\mathrm{N}$ & $\mathrm{FP}$ & 10 \\
\hline Gnaphalium viravira & Asteraceae & $\mathrm{N}$ & FP & $3,4,10$ \\
\hline Gochnatia foliolosa & Asteraceae & $\mathrm{E}$ & FP & $4,9,10$ \\
\hline Guindilia trinervis & Sapindaceae & $\mathrm{N}$ & $\mathrm{FP}$ & 10 \\
\hline Gutierrezia gayana & Asteraceae & $\mathrm{E}$ & $\mathrm{FP}$ & 10 \\
\hline Gutierrezia resinosa & Asteraceae & $\mathrm{E}$ & FP & $2,3,4$ \\
\hline Haplopappus arbutoides & Asteraceae & $\mathrm{N}$ & $\mathrm{FP}$ & 2 \\
\hline Haplopappus baylahuen & Asteraceae & $\mathrm{N}$ & $\mathrm{FP}$ & $2,3,4$ \\
\hline Haplopappus decurrens & Asteraceae & $\mathrm{E}$ & IC (FP?) & 2 \\
\hline Haplopappus deserticola & Asteraceae & $\mathrm{E}$ & IC (V?) & 2,4 \\
\hline Haplopappus elatus & Asteraceae & $\mathrm{E}$ & IC (E?) & 2 \\
\hline
\end{tabular}




\begin{tabular}{|c|c|c|c|c|}
\hline Scientific name & Family & Origin $^{1}$ & Conservation status $^{2}$ & Uses $^{3}$ \\
\hline Haplopappus foliosus & Asteraceae & $\mathrm{E}$ & FP & $2,3,4,6,9,10$ \\
\hline Haplopappus hirtellus & Asteraceae & $\mathrm{E}$ & FP & 2 \\
\hline Haplopappus illinitus & Asteraceae & $\mathrm{E}$ & IC (E?) & 2 \\
\hline Haplopappus integerrimus & Asteraceae & $\mathrm{E}$ & EP & 2,10 \\
\hline Haplopappus ischnos & Asteraceae & $\mathrm{E}$ & IC (V?) & 2 \\
\hline Haplopappus linifolius & Asteraceae & $\mathrm{E}$ & FP & 2 \\
\hline Haplopappus litoralis & Asteraceae & $\mathrm{E}$ & $\mathrm{V}$ & 2 \\
\hline Haplopappus meyenii & Asteraceae & $\mathrm{E}$ & $\mathrm{EP}$ & 2 \\
\hline Haplopappus paucidentatus & Asteraceae & $\mathrm{N}$ & IC & 2 \\
\hline Haplopappus philippii & Asteraceae & $\mathrm{E}$ & NE & 2 \\
\hline Haplopappus phyllophorus & Asteraceae & $\mathrm{E}$ & IC & 2 \\
\hline Haplopappus pinea & Asteraceae & $\mathrm{E}$ & IC (FP?) & 2 \\
\hline Haplopappus platylepis & Asteraceae & $\mathrm{E}$ & $\mathrm{V}$ & 2 \\
\hline Haplopappus pulchellus & Asteraceae & $\mathrm{E}$ & FP & 2 \\
\hline Haplopappus reicheanus & Asteraceae & $\mathrm{E}$ & IC (FP?) & 2 \\
\hline Haplopappus remyanus & Asteraceae & $\mathrm{E}$ & FP & 2 \\
\hline Haplopappus rengifoanus & Asteraceae & $\mathrm{E}$ & $\mathrm{V}$ & 2 \\
\hline Haplopappus rigidus & Asteraceae & $\mathrm{N}$ & IC & 2,3 \\
\hline Haplopappus scrobiculatus & Asteraceae & $\mathrm{N}$ & FP & 2 \\
\hline Haplopappus stelliger & Asteraceae & $\mathrm{E}$ & NE & 2 \\
\hline Haplopappus uncinatus & Asteraceae & $\mathrm{E}$ & IC (V?) & 2 \\
\hline Haplopappus velutinus & Asteraceae & $\mathrm{E}$ & FP & 2,4 \\
\hline Helenium aromaticum & Asteraceae & $\mathrm{N}$ & FP & 3,10 \\
\hline Heliotropium chenopodiaceum & Boraginaceae & $\mathrm{E}$ & FP & 10 \\
\hline Heliotropium curassavicum & Boraginaceae & $\mathrm{N}$ & FP & 10 \\
\hline Heliotropium geissei & Boraginaceae & $\mathrm{E}$ & IC (E?) & 10 \\
\hline Heliotropium longistylum & Boraginaceae & $\mathrm{E}$ & IC (V?) & 10 \\
\hline Heliotropium megalanthum & Boraginaceae & $\mathrm{E}$ & IC (V?) & 10 \\
\hline Heliotropium myosotifolium & Boraginaceae & $\mathrm{E}$ & IC (V?) & 10 \\
\hline Heliotropium paronychioides & Boraginaceae & $\mathrm{N}$ & FP & 10 \\
\hline Heliotropium sinuatum & Boraginaceae & $\mathrm{E}$ & FP & 10 \\
\hline Homalocarpus dichotomus & Apiaceae & $\mathrm{E}$ & FP & 10 \\
\hline Hypochaeris scorzonerae & Asteraceae & $\mathrm{E}$ & FP & 10 \\
\hline Jubaea chilensis & Palmae & $\mathrm{E}$ & $\mathrm{EP}$ & $1,5,7,10$ \\
\hline Junellia selaginoides & Verbenaceae & $\mathrm{E}$ & FP & 10 \\
\hline Junellia spathulata & Verbenaceae & $\mathrm{N}$ & IC (V?) & 10 \\
\hline Kageneckia angustifolia & Rosaceae & $\mathrm{E}$ & $\mathrm{EP}$ & $5,6,9,10$ \\
\hline Kageneckia oblonga & Rosaceae & $\mathrm{E}$ & $\mathrm{V}$ & $3,4,5,6,7,9,10$ \\
\hline Krameria cistoidea & Krameriaceae & $\mathrm{E}$ & FP & $1,2,3,4,7,10$ \\
\hline Larrea nitida & Zygophyllaceae & $\mathrm{N}$ & FP & $3,4,7,10$ \\
\hline Leucheria cerberoana & Asteraceae & $\mathrm{E}$ & FP & 10 \\
\hline Leucocoryne coquimbensis & Alliaceae & $\mathrm{E}$ & FP & 10 \\
\hline Leucocoryne dimorphopetala & Alliaceae & $\mathrm{E}$ & $\mathrm{V}$ & 10 \\
\hline Leucocoryne ixioides & Alliaceae & $\mathrm{E}$ & $\mathrm{V}$ & 10 \\
\hline Leucocoryne purpurea & Alliaceae & $\mathrm{E}$ & $\mathrm{V}$ & 2,10 \\
\hline Leucocoryne violacescens & Alliaceae & $\mathrm{E}$ & IC (V?) & 10 \\
\hline Llagunoa glandulosa & Sapindaceae & $\mathrm{E}$ & FP & $2,7,10$ \\
\hline Lobelia excelsa & Campanulaceae & $\mathrm{E}$ & FP & 4,10 \\
\hline Lobelia oligophylla & Campanulaceae & $\mathrm{N}$ & FP & 10 \\
\hline Lobelia polyphylla & Campanulaceae & $\mathrm{E}$ & FP & 4,10 \\
\hline Lomatia hirsuta & Proteaceae & $\mathrm{N}$ & IC (EP?) & $3,5,7,10$ \\
\hline Lupinus microcarpus & Fabaceae & $\mathrm{N}$ & FP & 9,10 \\
\hline Lycium stenophyllum & Solanaceae & $\mathrm{N}$ & IC (V?) & 10 \\
\hline Maihueniopsis grandiflora & Cactaceae & $\mathrm{E}$ & IC (V?) & $2,9,10$ \\
\hline Maihueniopsis wagenknechtii & Cactaceae & $\mathrm{E}$ & $\mathrm{V}$ & $2,9,10$ \\
\hline Malesherbia fasciculata & Malesherbiaceae & $\mathrm{E}$ & FP & 9,10 \\
\hline
\end{tabular}




\begin{tabular}{|c|c|c|c|c|}
\hline Scientific name & Family & Origin $^{1}$ & Conservation status $^{2}$ & Uses $^{3}$ \\
\hline Malesherbia humilis & Malesherbiaceae & $\mathrm{N}$ & FP & 10 \\
\hline Margyricarpus pinnatus & Rosaceae & $\mathrm{N}$ & FP & $1,3,4,7,10$ \\
\hline Menonvillea linearis & Brassicaceae & $\mathrm{E}$ & $\mathrm{V}$ & 10 \\
\hline Mentzelia bartonioides & Loasaceae & $\mathrm{N}$ & FP & 10 \\
\hline Mentzelia chilensis & Loasaceae & $\mathrm{E}$ & FP & 3,10 \\
\hline Mentzelia ignea & Loasaceae & $\mathrm{N}$ & IC (V?) & 10 \\
\hline Mentzelia pinnatifida & Loasaceae & $\mathrm{E}$ & FP & 10 \\
\hline Mirabilis elegans & Nyctaginaceae & $\mathrm{N}$ & IC (V?) & 10 \\
\hline Montiopsis sericea & Portulacaceae & $\mathrm{E}$ & $\mathrm{FP}$ & 10 \\
\hline Monttea chilensis & Scrophulariaceae & $\mathrm{E}$ & $\mathrm{EP}$ & $2,7,8,9,10$ \\
\hline Mutisia rosea & Asteraceae & $\mathrm{E}$ & IC (V?) & 3,10 \\
\hline Mutisia sinuata & Asteraceae & $\mathrm{N}$ & FP & 3,10 \\
\hline Myrceugenia obtusa & Myrtaceae & $\mathrm{E}$ & IC (E?) & 10 \\
\hline Myrceugenia rufa & Myrtaceae & $\mathrm{E}$ & $\mathrm{V}$ & 10 \\
\hline Nicotiana acuminata & Solanaceae & $\mathrm{N}$ & FP & 10 \\
\hline Nicotiana solanifolia & Solanaceae & $\mathrm{E}$ & IC & 10 \\
\hline Nolana acuminata & Nolanaceae & $\mathrm{E}$ & $\mathrm{V}$ & 10 \\
\hline Nolana baccata & Nolanaceae & $\mathrm{E}$ & IC (FP?) & 10 \\
\hline Nolana divaricata & Nolanaceae & $\mathrm{E}$ & $\mathrm{FP}$ & 10 \\
\hline Nolana glauca & Nolanaceae & $\mathrm{E}$ & IC & 10 \\
\hline Nolana paradoxa & Nolanaceae & $\mathrm{E}$ & FP & 10 \\
\hline Nolana rupicola & Nolanaceae & $\mathrm{EE}$ & $\mathrm{V}$ & 10 \\
\hline Nolana salsoloides & Nolanaceae & $\mathrm{E}$ & IC (E?) & 10 \\
\hline Ochagavia carnea & Bromeliaceae & $\mathrm{E}$ & IC (V?) & 10 \\
\hline Oenothera acaulis & Onagraceae & $\mathrm{N}$ & FP & 3,10 \\
\hline Oenothera affinis & Onagraceae & $\mathrm{N}$ & $\mathrm{V}$ & 10 \\
\hline Oenothera coquimbensis & Onagraceae & $\mathrm{E}$ & FP & 10 \\
\hline Oenothera stricta & Onagraceae & $\mathrm{N}$ & $\mathrm{FP}$ & 10 \\
\hline Olsynium junceum & Iridaceae & $\mathrm{N}$ & IC (E?) & 10 \\
\hline Olsynium philippii & Iridaceae & $\mathrm{E}$ & FP & 10 \\
\hline Olsynium scirpoideum & Iridaceae & $\mathrm{N}$ & FP & 10 \\
\hline Opuntia berteri & Cactaceae & $\mathrm{N}$ & FP & $2,9,10$ \\
\hline Opuntia glomerata & Cactaceae & $\mathrm{N}$ & $\mathrm{V}$ & $2,9,10$ \\
\hline Opuntia miquelii & Cactaceae & $\mathrm{E}$ & $\mathrm{FP}$ & $2,9,10$ \\
\hline Opuntia ovata & Cactaceae & $\mathrm{N}$ & FP & $2,4,9,10$ \\
\hline Opuntia tunicata & Cactaceae & $\mathrm{N}$ & $\mathrm{NE}$ & $2,9,10$ \\
\hline Oxalis arenaria & Oxalidaceae & $\mathrm{N}$ & IC & 10 \\
\hline Oxalis briquetii & Oxalidaceae & $\mathrm{E}$ & $\mathrm{NE}$ & 10 \\
\hline Oxalis compacta & Oxalidaceae & $\mathrm{N}$ & FP & 10 \\
\hline Oxalis coquimbana & Oxalidaceae & $\mathrm{E}$ & IC (V?) & 10 \\
\hline Oxalis erythrorhiza & Oxalidaceae & $\mathrm{N}$ & IC (E?) & 10 \\
\hline Oxalis gaudichaudii & Oxalidaceae & $\mathrm{E}$ & IC & 10 \\
\hline Oxalis gigantea & Oxalidaceae & $\mathrm{E}$ & $\mathrm{FP}$ & $2,7,10$ \\
\hline Oxalis glutinosa & Oxalidaceae & $\mathrm{E}$ & IC (V?) & 10 \\
\hline Oxalis illapelina & Oxalidaceae & $\mathrm{E}$ & IC (V?) & 10 \\
\hline Oxalis laxa & Oxalidaceae & $\mathrm{N}$ & $\mathrm{FP}$ & 10 \\
\hline Oxalis maritima & Oxalidaceae & $\mathrm{E}$ & $\mathrm{V}$ & 7,10 \\
\hline Oxalis micrantha & Oxalidaceae & $\mathrm{N}$ & FP & 10 \\
\hline Oxalis ovalleana & Oxalidaceae & $\mathrm{E}$ & $\mathrm{IC}$ & 10 \\
\hline Oxalis paniculata & Oxalidaceae & $\mathrm{E}$ & IC (E?) & 10 \\
\hline Oxalis perdicaria & Oxalidaceae & $\mathrm{N}$ & FP & 10 \\
\hline Oxalis rosea & Oxalidaceae & $\mathrm{E}$ & $\mathrm{FP}$ & $1,2,7,10$ \\
\hline Oxalis san-romanii & Oxalidaceae & $\mathrm{N}$ & FP & 10 \\
\hline Oxalis squarrosa & Oxalidaceae & $\mathrm{E}$ & FP & 10 \\
\hline Oxalis succulenta & Oxalidaceae & $\mathrm{E}$ & $\mathrm{IC}$ & 10 \\
\hline Oxalis tarapacana & Oxalidaceae & $\mathrm{E}$ & $\mathrm{IC}$ & 10 \\
\hline
\end{tabular}




\begin{tabular}{|c|c|c|c|c|}
\hline Scientific name & Family & Origin $^{1}$ & Conservation status $^{2}$ & Uses $^{3}$ \\
\hline Oxalis tortuosa & Oxalidaceae & $\mathrm{E}$ & FP & 10 \\
\hline Oziroe biflora & Hyacinthaceae & $\mathrm{N}$ & FP & 10 \\
\hline Pasithea caerulea & Hemerocallidaceae & $\mathrm{N}$ & FP & 10 \\
\hline Perezia carthamoides & Asteraceae & $\mathrm{N}$ & FP & $3,4,10$ \\
\hline Perityle emoryi & Asteraceae & $\mathrm{N}$ & IC (V?) & $3,4,10$ \\
\hline Peumus boldus & Monimiaceae & $\mathrm{E}$ & $\mathrm{V}$ & $1,3,4,6,7,9,10$ \\
\hline Phacelia brachyantha & Hydrophyllaceae & $\mathrm{N}$ & $\mathrm{V}$ & 10 \\
\hline Phacelia secunda & Hydrophyllaceae & $\mathrm{N}$ & FP & 10 \\
\hline Phrodus microphyllus & Solanaceae & $\mathrm{E}$ & FP & 10 \\
\hline Pleurophora pungens & Lythraceae & $\mathrm{E}$ & FP & 10 \\
\hline Plumbago caerulea & Plumbaginaceae & $\mathrm{N}$ & FP & 10 \\
\hline Podanthus mitiqui & Asteraceae & $\mathrm{E}$ & FP & $2,3,4,10$ \\
\hline Polyachyrus carduoides & Asteraceae & $\mathrm{E}$ & $\mathrm{FP}$ & 2 \\
\hline Polyachyrus fuscus & Asteraceae & $\mathrm{N}$ & FP & 4,10 \\
\hline Polyachyrus poeppigii & Asteraceae & $\mathrm{E}$ & FP & 10 \\
\hline Porlieria chilensis & Zygophyllaceae & $\mathrm{E}$ & $\mathrm{V}$ & $2,4,5,7,10$ \\
\hline Pouteria splendens & Sapotaceae & $\mathrm{E}$ & EP & 10 \\
\hline Prosopis flexuosa & Mimosaceae & $\mathrm{N}$ & EP & $8,9,10$ \\
\hline Prosopis strombulifera & Mimosaceae & $\mathrm{N}$ & FP & $7,8,9,10$ \\
\hline Proustia cuneifolia & Asteraceae & $\mathrm{E}$ & FP & $3,4,8,10$ \\
\hline Proustia pyrifolia & Asteraceae & $\mathrm{E}$ & EP & $5,6,10$ \\
\hline Pteromonnina pterocarpa & Polygalaceae & $\mathrm{N}$ & $\mathrm{V}$ & 10 \\
\hline Puya alpestris & Bromeliaceae & $\mathrm{N}$ & IC (E?) & $5,7,8,9,10$ \\
\hline Puya berteroniana & Bromeliaceae & $\mathrm{E}$ & FP & $1,3,5,6,7,8,9,10$ \\
\hline Puya chilensis & Bromeliaceae & $\mathrm{E}$ & FP & $1,2,3,4,5,7,8,9,10$ \\
\hline Puya coerulea & Bromeliaceae & $\mathrm{E}$ & $\mathrm{NE}$ & $5,7,8,9,10$ \\
\hline Puya gilmartiniae & Bromeliaceae & $\mathrm{E}$ & IC (E?) & $5,7,8,9,10$ \\
\hline Puya venusta & Bromeliaceae & $\mathrm{E}$ & FP & $5,7,8,9,10$ \\
\hline Quinchamalium chilense & Santalaceae & $\mathrm{N}$ & FP & $3,4,10$ \\
\hline Ranunculus peduncularis & Ranunculaceae & $\mathrm{N}$ & IC (V?) & 3,10 \\
\hline Retanilla trinervia & Rhamnaceae & $\mathrm{E}$ & FP & $2,3,4,6,9,10$ \\
\hline Satureja gilliesii & Labiatae & $\mathrm{E}$ & FP & $3,4,9,10$ \\
\hline Schizopetalon bipinnatifidum & Brassicaceae & $\mathrm{E}$ & FP & 10 \\
\hline Schizopetalon maritimum & Brassicaceae & $\mathrm{E}$ & FP & 10 \\
\hline Schizopetalon walkeri & Brassicaceae & $\mathrm{E}$ & $\mathrm{V}$ & 10 \\
\hline Senecio eruciformis & Asteraceae & $\mathrm{N}$ & FP & $3,9,10$ \\
\hline Senecio murorum & Asteraceae & $\mathrm{E}$ & FP & $4,9,10$ \\
\hline Senna candolleana & Caesalpiniaceae & $\mathrm{E}$ & FP & $3,5,10$ \\
\hline Sicyos baderoa & Cucurbitaceae & $\mathrm{N}$ & FP & 10 \\
\hline Sisyrinchium arenarium & Iridaceae & $\mathrm{N}$ & FP & 10 \\
\hline Sisyrinchium graminifolium & Iridaceae & $\mathrm{N}$ & $\mathrm{V}$ & 7,10 \\
\hline Sisyrinchium striatum & Iridaceae & $\mathrm{N}$ & $\mathrm{V}$ & 3,10 \\
\hline Skytanthus acutus & Apocynaceae & $\mathrm{E}$ & EP & $2,4,9,10$ \\
\hline Solanum heterantherum & Solanaceae & $\mathrm{E}$ & FP & 10 \\
\hline Solanum ligustrinum & Solanaceae & $\mathrm{N}$ & FP & $3,4,10$ \\
\hline Solanum remyanum & Solanaceae & $\mathrm{E}$ & IC (V?) & 10 \\
\hline Sophora macrocarpa & Fabaceae & $\mathrm{E}$ & $\mathrm{EP}$ & $4,7,10$ \\
\hline Sphacele chamaedryoides & Labiatae & $\mathrm{E}$ & IC (E?) & 10 \\
\hline Sphacele salviae & Labiatae & $\mathrm{E}$ & $\mathrm{FP}$ & $3,7,9,10$ \\
\hline Sphaeralcea obtusiloba & Malvaceae & $\mathrm{E}$ & FP & $2,3,10$ \\
\hline Stachys eremicola & Labiatae & $\mathrm{E}$ & $\mathrm{V}$ & 9 \\
\hline Stachys grandidentata & Labiatae & $\mathrm{E}$ & FP & 9,10 \\
\hline Stachys pannosa & Labiatae & $\mathrm{E}$ & IC (V?) & 9 \\
\hline Stachys philippiana & Labiatae & $\mathrm{E}$ & IC (V?) & 9,10 \\
\hline Suaeda foliosa & Chenopodiaceae & $\mathrm{N}$ & FP & 10 \\
\hline Tecophilaea violiflora & Tecophilaeaceae & $\mathrm{E}$ & $\mathrm{FP}$ & 10 \\
\hline
\end{tabular}




\begin{tabular}{|c|c|c|c|c|}
\hline Scientific name & Family & Origin $^{1}$ & Conservation status $^{2}$ & Uses $^{3}$ \\
\hline Tetraglochin alatum & Rosaceae & $\mathrm{N}$ & FP & 10 \\
\hline Tetragonia angustifolia & Aizoaceae & $\mathrm{E}$ & IC & 10 \\
\hline Tetragonia maritima & Aizoaceae & $\mathrm{E}$ & FP & 10 \\
\hline Tetragonia ovata & Aizoaceae & $\mathrm{E}$ & IC (V?) & 10 \\
\hline Teucrium bicolor & Labiatae & $\mathrm{E}$ & $\mathrm{FP}$ & $3,4,10$ \\
\hline Teucrium nudicaule & Labiatae & $\mathrm{E}$ & FP & 10 \\
\hline Tillandsia capillaris & Bromeliaceae & $\mathrm{N}$ & $\mathrm{FP}$ & 10 \\
\hline Tillandsia geissei & Bromeliaceae & $\mathrm{E}$ & IC (EP?) & 10 \\
\hline Tillandsia landbeckii & Bromeliaceae & $\mathrm{N}$ & FP & 10 \\
\hline Trevoa quinquenervia & Rhamnaceae & $\mathrm{E}$ & $\mathrm{V}$ & $2,4,6,8,9,10$ \\
\hline Trichopetalum plumosum & Lomandraceae & $\mathrm{E}$ & FP & 10 \\
\hline Triptilion gibbosum & Asteraceae & $\mathrm{E}$ & FP & 10 \\
\hline Triptilion spinosum & Asteraceae & $\mathrm{E}$ & IC & 4,10 \\
\hline Tristerix verticillatus & Loranthaceae & $\mathrm{N}$ & FP & $4,7,9$ \\
\hline Tropaeolum azureum & Tropaeolaceae & $\mathrm{E}$ & FP & 10 \\
\hline Tropaeolum brachyceras & Tropaeolaceae & $\mathrm{E}$ & $\mathrm{V}$ & 10 \\
\hline Tropaeolum hookerianum & Tropaeolaceae & $\mathrm{E}$ & $\mathrm{V}$ & 10 \\
\hline Tropaeolum jilesii & Tropaeolaceae & $\mathrm{E}$ & IC (E?) & 10 \\
\hline Tropaeolum kingii & Tropaeolaceae & $\mathrm{E}$ & FP & 10 \\
\hline Tropaeolum looseri & Tropaeolaceae & $\mathrm{E}$ & FP & 10 \\
\hline Tropaeolum polyphyllum & Tropaeolaceae & $\mathrm{N}$ & FP & 10 \\
\hline Tropaeolum sessilifolium & Tropaeolaceae & $\mathrm{E}$ & FP & 10 \\
\hline Tropaeolum tricolor & Tropaeolaceae & $\mathrm{E}$ & FP & 10 \\
\hline Tweedia birostrata & Asclepiadaceae & $\mathrm{E}$ & FP & 10 \\
\hline Tweedia stipitata & Asclepiadaceae & $\mathrm{E}$ & FP & 10 \\
\hline Vicia vicina & Fabaceae & $\mathrm{E}$ & IC (V?) & 2,10 \\
\hline Viola polypoda & Violaceae & $\mathrm{E}$ & $\mathrm{V}$ & 10 \\
\hline Viviania crenata & Vivianiaceae & $\mathrm{E}$ & FP & 2,10 \\
\hline Viviania marifolia & Vivianiaceae & $\mathrm{N}$ & FP & $2,3,10$ \\
\hline Zephyra elegans & Tecophilaeaceae & E & $\mathrm{FP}$ & 10 \\
\hline
\end{tabular}

${ }^{1} \mathrm{E}$, endemic to Chile; $\mathrm{N}$, native to Chile.

${ }^{2} \mathrm{FP}$ : out of danger, IC(E?): insufficiently known (extinct?), IC(FP?): insufficiently known (out of danger?), IC(V?): insufficiently known (vulnerable?), V: vulnerable.

${ }^{3} 1$ : alimentary, 2: cattle forage, 3: medicinal, 4: phytochemical, 5: timber/construction, 6: fuel, 7: crafts, 8: soil conservation, 9: mellipherous, 10: ornamental.

ing deposits and that have additional uses, 19 are in danger of extinction, 56 are in a state of vulnerability and 120 are insufficiently known (Table 2). It is noteworthy that in these two groups of species, 31 species have been cataloged as insufficiently known and are suspected of being extinct (Marticorena et al., 2001), as this reduces the number of species potentially utilizable in phytostabilization projects. The inclusion of endangered and vulnerable species in phytostabilization programs could undoubtedly aid their conservation, as long as sustainable management is carried out.

It is worth mentioning that the main objective is the stabilization of mining tailings, and that the additional use of the species for another purpose should not interfere with that goal. Within the uses proposed for the flora to be used in phytostabilization of mining tailings, there are several involving the use of vegetative structures that are important or essential for the plant's survival, such as food, forage, medicine, phytochemicals, timber/construction, fuel and handicrafts. In these cases, it becomes crucial to provide a sustainable plan for harvesting the structures of interest, so that the utilization of the species does not detract from the stabilization of the mining wastes.

\section{Final considerations}

Even though many of the uses described for the vegetal species of the Region of Coquimbo are restricted to disappearing indigenous cultures or rural local subsistence communities, there is real potential for the use of the native regional 
flora. Ongoing study of the plants has made evident the existence of high-value chemical compounds. This potentiates the generation of new markets where the flora traditionally used by indigenous cultures and local communities reach consumers at commercial levels. In this way, sustainably managed native flora could contribute to their own conservation by creating value. It is worth noting that even though there may be significant economic and subsistence benefits to conserving the native flora, if those benefits are not sensed or valued as significant by local users, support for the conservation of that resource will be absent (Campbell, 2000).

The added value provided to a phytostabilization program by a sustainably managed native vegetal species with additional uses would favor this technology over other methods used to stabilize mining wastes. Using such a program to rehabilitate areas contaminated by mining activities and to restore local ecosystems might also preserve and enhance biodiversity. However, more extensive studies are required before the potential uses we identified can be developed to a productive level. Additionally, to select the best species for use in post-operative mining tailing phytostabilization programs, the tolerances and metal accumulation capacities of these species must be determined with biotests.

In order to enrich the quality of life of the rural population of the region, as well as to enhance biodiversity and ecosystem productivity, it is necessary to attempt to alleviate the environmental problems generated by mining activities. Mining rehabilitation through phytostabilization presents an opportunity to address all these aspects as a whole.

\section{Resumen}

C. Orchard, P. León-Lobos y R. Ginocchio. 2009. Fitoestabilización de desechos mineros masivos con recursos fitogenéticos nativos: Potencial para el uso sustentable y la conservación de la flora nativa de la zona centro-norte de Chile. Cien. Inv. Agr. 36(3):329-

352. La minería metálica ha dejado una gran cantidad de depósitos de relaves en la zona centronorte de Chile inadecuadamente abandonados, significando un riesgo para el ambiente. Por ello, la actual normativa minera chilena enfatiza la estabilización de estos depósitos para su adecuado cierre, favoreciendo el uso de tecnologías ambientalmente sustentables. Entre ellas se encuentra la fitoestabilización, tecnología que puede ser favorecida al incorporar especies que proporcionen usos económicos y de subsistencia. La incorporación de especies nativas en programas de fitoestabilización y su aprovechamiento sustentable podrían aportar, también, en la conservación de la flora nativa y de los ecosistemas de la zona centro-norte de Chile. En esta investigación, se indagó sobre los usos alternativos que podrían tener las especies nativas que han colonizando espontáneamente depósitos de relaves abandonados y de otras especies que, dadas sus características ecológicas, podrían establecerse sobre tranques de relaves postoperativos en el marco de la tecnología de fitoestabilización, tomando la Región de Coquimbo como caso de estudio. Se realizó una revisión de la literatura científica, técnica y etnobotánica sobre los usos tradicionales y aquellos que se han descubierto recientemente de las especies nativas de la Región. Los resultados indicaron que 68 especies colonizadoras espontáneas tienen al menos un uso conocido, mientras que 420 especies con potencial de utilización en programas de fitoestabilización, un $28 \%$ de la flora nativa regional, presentan posibles usos que brindarían un beneficio adicional a la estabilización de estos depósitos. Entre los principales usos identificados se encuentran el ornamental, forrajero, apícola, medicinal, principio químico y artesanal. Un 69\% de estas especies son endémicas de Chile, constituyendo un valioso recurso fitogenético en la mitigación de problemas ambientales relacionados con el sector minero, que podrían perderse si no se identifican y estudian a tiempo.

Palabras clave: Manejo sustentable, minería, rehabilitación, tranques de relaves, valoración de recursos naturales. 


\section{References}

Bell, L.C. 1999. A multidisciplinary approach to producing solutions for sustainable mine rehabilitation - the role of the australian centre for mine site rehabilitation research. Pages 3-11. In: M.H. Wong, J.W.C. Wong, and A.M.J. Baker (eds.). Remediation and Management of Degraded Lands. CRC Press LLC. Florida, USA.

Berti, W. R. and S.D. Cunninghan. 2000. Phytostabilization of metals. Pages 71-88. In: I. Raskin and B.D. Ensley (eds.). Phytoremediation of Toxic Metals: Using Plants to Clean up the Environment. Wiley Inter-Science. NY, USA.

Brown, G., P. Jara-Seguel, F. J. López-Cortés, and J. M. Viada. 2003. Texto regional de educación ambiental. Cuarta Región de Coquimbo, de mar a cordillera. Comisión Nacional del Medio Ambiente y Ministerio de Educación. Santiago, Chile. $178 \mathrm{p}$.

Bustamante, W. 1994. Análisis de propuestas tecnológicas para el mejoramiento de las condiciones socioambientales en comunidades agrícolas de Coquimbo (IV Región-Chile). Documento Técnico $\mathrm{N}^{\circ}$ 17. Pontificia Universidad de Chile. Facultad de Ingeniería. Escuela de Construcción Civil. Santiago, Chile. 96 p.

Bustamante, R.A. 1996. Distribución, estado de conservación y uso de las cactáceas columnares en la Región de Coquimbo. Tesis Ingeniero Agrónomo, Facultad de Agronomía, Universidad de Chile, Santiago, Chile. 143 p.

Campbell, L.M. 2000. Human need in rural developing areas: perceptions of wildlife conservation experts. The Canadian Geographer/Le Géographe canadien 44:167-181.

Conesa, H. M., R. Schulin, and B. Nowack. 2007. A laboratory study on revegetation and metal uptake in native plant species from neutral mine tailings. Water, Air and Soil Pollution 183:201212.

Dietz, A.C., and J.L. Schnoor. 2001. Advances in phytoremediation. Environmental Health Perspectives 109: 163-168.

Dobson, A. P., A. D. Bradshaw, and A.J.M. Baker. 1997. Hopes for the future: restoration ecology and conservation biology. Science 277:515-522.

Dold, B. 2007. Biogeochemical processes in mine tailings with special focus on marine shore tailings deposits and their remediation. Advanced Materials Research 20-21:177-185.
Espinoza, G., P. Gross, and E.R. Hajek. 1991. Problemas Ambientales de la Región de Coquimbo (IV Región). Comisión Nacional del Medio Ambiente (CONAMA). Secretaría Técnica y Administrativa, Santiago, Chile.

Fernández, M.C., E. Subrá, and A. Ortiz. 1994. La miel, indicador ambiental. Páginas 37-46. En: Prácticas Ecológicas para una Agricultura de Calidad. I Congreso de la Sociedad Española de Agricultura Ecológica (Proceedings). Toledo. España.

Folchi, M. 2001. La insustentabilidad de la industria del cobre en Chile: los hornos y los bosques durante el siglo XIX. Mapocho 49:149-175.

Ginocchio, R. 2004. Nueva tecnología: fitoestabilización para cierres de faenas mineras. Sustentare, Minería Chilena 21:1-4.

Ginocchio, R. 2008. Uso de recursos fitogenéticos nativos para la fitoestabilización de relaves mineros en la Región de Coquimbo. Informe Técnico Final, Proyecto Innova Chile de CORFO $\mathrm{N}^{\circ}$ 04CR9IXD-01. Centro de Investigación Minera y Metalúrgica, CIMM. Santiago, Chile.

Ginocchio, R., and A.J. Baker. 2004. Metallophytes in Latin America: a remarkable biological and genetic resource scarcely known and studied in the region. Revista Chilena de Historia Natural 77:185-194.

Ginocchio, R., and P. León-Lobos. 2007. Recursos genéticos para la fitoestabilización: plantas que reducen la contaminación por desechos mineros. Tierra Adentro 75:20-23.

Ginocchio, R., Santibáñez, C., León-Lobos, P., Brown, S., Baker, A.J.M. 2007. Sustainable rehabilitation of copper mine tailings in Chile through phytostabilization: more than plants. Pages 465-474. In: A. Fourie, M. Tibbet, and J. Wiertz (eds.). Mine Closure 2007. Proceedings of the Second International Seminar on Mine Closure. Australian Centre for Geomechanics. Perth, Australia

Glass, D.J. 2000. Economic potential of phytoremediation. Pages 5-31.In: I. Raskin, and B.D. Ensley (eds.). Phytoremediation of toxic metals: using plants to clean up the environment. Wiley Inter-Science. NY, USA.

Goodman, G.T. 1974. Ecology and the problems of rehabilitating wastes from mineral extraction. Proceedings of the Royal Society A 339:373387.

ICMM. 2006. Guía de Buenas Prácticas para la Minería y la Biodiversidad. International Council on 
Mining and Metals. Londres, Reino Unido. 166

p.

INE. 2008. Informe Económico Regional EneroMarzo de 2008. Instituto Nacional de Estadísticas (INE). Santiago, Chile. 76 p.

IUCN, and ICMM. 2004. Integrating mining and biodiversity conservation: case studies from around the world. International Union for Conservation of Nature and Natural Resources and International Council on Mining and Metals. 48 p.

Jorquera, C. 2001. La agricultura regional y el deterioro de la vegetación nativa: una visión actualizada. Páginas 239-251. En: F.A. Squeo, G. Arancio y J.R. Gutiérrez (eds.). Libro Rojo de la Flora Nativa y de los Sitios Prioritarios para su Conservación: Región de Coquimbo. Ediciones Universidad de La Serena. La Serena, Chile.

León-Lobos, P., G. Tapia, and C. Ortiz. 2007. Recursos fitogenéticos. Pilares de la innovación biotecnológica en Chile. Tierra Adentro 75:14-17.

López, P., S. Ainzúa, C. Zolezzi, and P. Vasconi. 2003. La Minería y Su Pasivo Ambiental. Publicaciones Terram. Análisis de Políticas Públicas (AAP) 24. Santiago, Chile.

Lyon, G.L. 1991. Bases Biológicas para la Regeneración in vitro de Alstroemeria. Tesis Ingeniero Agrónomo, Facultad de Agronomía e Ingeniería Forestal, Pontificia Universidad Católica de Chile, Santiago, Chile. 114 p.

Mahmud, R., N. Inouse, S. Kasajima, and R. Shaheen. 2008. Assessment of potential indigenous plant species for the phytoremediation of arseniccontaminated areas of Bangladesh. International Journal of Phytoremediation 10:119-132.

Marticorena, C., F. A. Squeo, G. Arancio, and M. Muñoz. 2001. Catálogo de la flora vascular de la IV Región de Coquimbo. Páginas 105-142. En: F.A. Squeo, G. Arancio y J.R. Gutiérrez (eds.). Libro rojo de la Flora Nativa y de los Sitios Prioritarios para su Conservación: Región de Coquimbo. Ediciones Universidad de La Serena. La Serena, Chile.

Martin, T.A., and M.V. Ruby. 2004. Review of in situ remediation technologies for lead, zinc, and cadmium in soil. Remediation Journal 14:35-53.

Mendez, M.O., and R.M. Maier. 2008. Phytostabilization of mine tailings in arid and semiarid environments - an emerging remediation technology. Environmental Health Perspectives 116:278283.

Miller, R.R. 1996. Phytoremediation. Ground-Water Remediation Technologies Analysis Center,
GWRTAC, O Series Reports, TO-96-03.

Ministerio de Minería. 2004. Reglamento de seguridad minera. Decreto Supremo No 132. Gobierno de Chile, Santiago, Chile.

Ministerio de Minería. 2007. Reglamento para la aprobación de proyectos de diseño, construcción, operación y cierre de los depósitos de relaves. Decreto Supremo No 248. Gobierno de Chile, Santiago, Chile.

Montenegro, G. 2000. Chile nuestra flora útil. Ediciones Universidad Católica de Chile. Santiago, Chile. 267pp.

Myers, N.,R.A. Mittermeier, C.G. Mittermeier, G.A.B. da Fonseca, and J. Kent. 2000. Biodiversity hotspots for conservation priorities. Nature 403:853-858.

Novoa, J. E., and D. López. 2001. IV Región: el escenario geográfico físico. Páginas 13-28.En: F.A. Squeo, G. Arancio y J.R. Gutiérrez (eds.). Libro Rojo de la Flora Nativa y de los Sitios Prioritarios para su Conservación: Región de Coquimbo. Ediciones Universidad de La Serena. La Serena, Chile.

Pastor, M. R., J. Vilela, and C. Cabello. 1997. Especies arbóreas y arbustivas para las zonas áridas y semiáridas de América latina. Serie: Zonas áridas y semiáridas $\mathrm{N}^{\circ} 12$. Oficina regional de la FAO para América Latina y el Caribe, Organización de las Naciones Unidas para la Agricultura y la Alimentación. Santiago, Chile. 347 pp.

Petrisor, I. G., S. Dobrota, K. Komnitsas, I. Lazar, J. M. Kuperberg, and M. Serban. 2004. Artificial inoculation-perspectives in tailings phytostabilization. International Journal of Phytoremediation 6:1-15.

Piha, M. I., H. W. Vallack, B. M. Reeler, and N. Michael. 1995. A low input approach to vegetation establishment on mine and coal ash wastes in semi-arid regions. I. Tin mine tailings in Zimbabwe. Journal of Applied Ecology 32:372-381.

Prasad, M. N., and H. M. Freitas. 2003. Metal hyperaccumulation in plants - biodiversity prospecting for phytoremediation technology. Electronic Journal of Biotechnology 6:285-321.

Primack, R., and F. Massardo. 2001. Restauración ecológica. Páginas 559-582. En: R. Primack, R. Rozzi, P. Feinsinger, R. Dirzo y F. Massardo (eds.). Fundamentos de conservación biológica perspectivas latinoamericanas. Fondo de Cultura Económica. México, D. F., Mexico.

Primack, R., R. Rozzi, P. Feinsinger, and F. Massardo. 2001. Conservación fuera de las áreas 
protegidas. Páginas 521-557. En: R. Primack, R. Rozzi, P. Feinsinger, R. Dirzo y F. Massardo (eds.). Fundamentos de conservación biológica perspectivas latinoamericanas. Fondo de Cultura Económica. México, D. F.

Riedemann, P., G. Aldunate, and S. Teillier. 2006. Flora Nativa de Valor Ornamental, Identificación y Propagación, Chile zona norte. 404 p.

Romo, M., V. Castro, C. Villagrán, and C. Latorre. 1999. La transición entre las tradiciones de los oasis del desierto y de las quebradas altas del Loa superior: etnobotánica del Valle del Río Grande, II Región, Chile. Chungara Revista de Antropología Chilena 31:319-360.

Rubio, J. 2007. Efluentes en la mira. Induambiente $86: 24-28$.

Sánchez, L.E. 2002. Impactos sobre los ecosistemas. Páginas 322-331. En: F.L. Repetto y C.L. Karez (eds.). Notas de clases dictadas en el II curso internacional de aspectos geológicos de protección ambiental. Oficina Regional de Ciencia de la UNESCO para América Latina y el Caribe. Montevideo, Uruguay.

Santibáñez, C.C. 2006. Uso de biosólidos de plantas de tratamiento de aguas servidas y ballica para la fitoestabilización de tranques de relaves. Tesis de Doctorado en Ciencias Silvoagropecuarias y Veterinarias. Facultad de Ciencias Agropecuarias y Forestales, Universidad de Chile, Santiago, Chile. 103 p.

SERNAGEOMIN. 1990. Levantamiento catastral de los tranques de relave en Chile. Etapa B, regiones IV, V y VII. Servicio Nacional de Geología y Minería, Santiago, Chile.

Silva, M., and M. Bittner. 1992. Algunos compuestos de interés biológico aislados de la flora chilena. Páginas 285-305. En: O. Muñoz (ed.). Química de la Flora de Chile. Dirección General Académica y Estudiantil, Universidad de Chile, Santiago, Chile.

SONAMI. 2006. En plena ejecución fitoestabilización de tranques de relave. Boletín Minero 1199:18-21.

Squeo, F.A., and M.T.K. Arroyo. 2001. Presentación científica del libro rojo de la flora nativa y de los sitios prioritarios para su conservación: Región de Coquimbo. Páginas 3-11. En: F.A. Squeo, G. Arancio y J. R. Gutiérrez (eds.). Libro Rojo de la Flora Nativa y de los Sitios Prioritarios para su Conservación: Región de Coquimbo. Ediciones Universidad de La Serena. La Serena, Chile.

Squeo, F. A., G. Arancio, C. Marticorena, M. Muñoz, and J. R. Gutiérrez. 2001a. Diversidad vegetal de la IV Región de Coquimbo, Chile. Páginas149158. En: F.A. Squeo, G. Arancio y J.R. Gutiérrez (eds.). Libro Rojo de la Flora Nativa y de los Sitios Prioritarios para su Conservación: Región de Coquimbo. Ediciones Universidad de La Serena. La Serena, Chile.

Squeo, F. A., G. Arancio, L. Cavieres, J. R. Gutiérrez, M. Muñoz, and C. Marticorena. 2001b. Análisis del estado de conservación de la flora nativa de la IV Región de Coquimbo. Páginas 53-62. En: F.A. Squeo, G. Arancio y J.R. Gutiérrez (eds.). Libro Rojo de la Flora nativa y de los Sitios Prioritarios para su Conservación: Región de Coquimbo. Ediciones Universidad de La Serena. La Serena, Chile.

Vega, A. 1999. Minería y medio ambiente. Ministerio de Educación. Santiago, Chile. 44 p.

Whiting, S.N., R.D. Reeves, D. Richards, M.S. Johnson, J.A. Cooke, F. Malaisse, A. Paton, J.A.C. Smith, J.S. Angle, R.L. Chaney, R. Ginocchio, T. Jaffré , R. Johns, T. McIntyre, O.W. Purvis, D.E. Salt, H. Schat, F.J. Zhao, and A.J.M. Baker. 2004. Research priorities for conservation of metallophyte biodiversity and their potential for restoration and site remediation. Restoration Ecology 12:106-116.

Wilhelm de Mösbach, E. 1992. Botánica indígena de Chile. Editorial Andrés Bello, Santiago, Chile. $140 \mathrm{p}$.

Yazbek, O. 2002. Recuperación de áreas degradadas por la minería en regiones urbanas. En: F.L. Repetto, and C.L. Karez. Páginas 332-345 (eds.). Notas de Clases Dictadas en el II Curso Internacional de Aspectos Geológicos de Protección Ambiental. Oficina Regional de Ciencia de la UNESCO para América Latina y el Caribe. Montevideo, Uruguay.

Young, T.P. 2000. Restoration ecology and conservation biology. Biological Conservation 92:73-83. 
